\title{
Say-on-Pay in a Context of Concentrated Ownership: Evidence from Italy
}

\author{
Massimo Belcredi* \\ Stefano Bozzi* \\ Angela Ciavarella \\ Valerio Novembre
}

December 2013

\begin{abstract}
We investigate say-on-pay (SOP) voting outcomes in a country (Italy) where ownership structure is concentrated by regressing shareholder dissent on a comprehensive set of independent variables (spanning from remuneration structure and disclosure to corporate governance), coming from the Italian Securities and Exchange Commission (CONSOB) and the Listed companies' industry association (Assonime-Emittenti Titoli) databases. Our main results may be summarized as follows: a) shareholder dissent in Italy is smaller, but still comparable with that found in the UK and the US, where ownership is disperse; b) dissent is negatively correlated with the equity stake held by the largest shareholder; we interpret this evidence as consistent with better monitoring and lower agency costs; c) dissent is, at best, only weakly related with company performance; however, it is positively correlated with CEO remuneration and negatively correlated with the level of disclosure, especially on the variable components of CEO pay; d) dissent is affected by investor activism at the company level, as proxied by the turnout of institutional investors at the AGM and by minority directors (a peculiar feature of Italian CG regulation) sitting on the board of target companies; e) finally, dissent is higher where shareholders' SOP vote is non-binding, implying that the nonbinding nature of the SOP vote does not reduce its effectiveness.
\end{abstract}

EFM Classification codes: $150,190,540$

Keywords: say-on-pay, remuneration, shareholder activism, institutional investors, corporate governance, concentrated ownership, shareholders' meeting.

\footnotetext{
* Università Cattolica del S.Cuore, Milano, and ECGI. Via Necchi 5, 20123 Milan. Phone: +39 0272342457. Fax: +39 02 72342766. Email: massimo.belcredi@unicatt.it.

* Università Cattolica del S.Cuore, Milano. Via Necchi 5, 20123 Milan. Phone: +39 0272344101 . Fax: +39 02 72342766. Email: stefano.bozzi@unicatt.it.

- Research Department, CONSOB, Via G.B. Martini 3, 00198 Rome. Phone +39 068477946. Fax: +39 068477612. Email: a.ciavarella@ consob.it.

- Research Department, CONSOB, Via G.B. Martini 3, 00198 Rome. Phone +39 068477297. Fax: +39 068477612. Email: v.novembre@consob.it.
} 


\section{Say-on-Pay in a Context of Concentrated Ownership: Evidence from Italy}

\section{Introduction ${ }^{1}$}

The aim of this paper is to investigate the factors driving shareholders' dissent on remuneration policies in Italian listed companies. At the end of 2010, Italy introduced a regulation requiring companies to publish a remuneration report and to submit a remuneration policy to a mandatory non-binding shareholder vote. The political intervention, aligning the Italian regulation with EU recommendations, followed strong public outrage arising from a number of episodes where corporate executives received huge payments, although their relation with corporate results (and also with their tenure as CEOs, in case of severance payments) seemed, at best, thin. Further, especially after the 2008 Lehman collapse, the media have highlighted that pay packages are often not aligned with the interest of shareholders, and this may have encouraged excessive risk-taking (Bhagat \& Romano 2009; Bebchuk \& Spamann 2012). Our paper provides the first evidence on whether say on pay mechanism has been used by shareholders of Italian listed companies to express their dissatisfaction on remuneration policy and examines the factors behind it.

Executive remuneration has long been considered a key variable of corporate governance in that it can allow in principle a better alignment of the management's interests with those of the shareholders. In a context of asymmetric information, the optimal contracting theory suggests that an efficient remuneration contract, namely one with a fine-tuned mix of fixed and variable components, might effectively overcome agency problems (Jensen \& Meckling 1976; Fama \& Jensen 1983; Jensen \& Murphy 1990). However, these theoretical predictions are not always grounded. Actually, the competing rent extraction view seems to show a stronger explanatory power by hypothesizing that managers are able to influence the pay process to their own benefit (La Porta, Lopez-de-Silanes \& Shleifer 1999; Bebchuk, Fried \& Walker 2002; Bebchuk \& Fried 2006).

In reaction to the increasing evidence of rent extraction, politicians and regulators have advocated various reforms aimed at increasing transparency and shareholders' involvement. While giving shareholders more information on the awarded pay packages is certainly relevant, illustrating the remuneration policy behind them and providing shareholders with a say is key to promote their active engagement as a catalyst of market pressure. Several countries, namely the US and UK, but also the Netherlands, Sweden, Norway, Denmark, Germany, Australia, etc., have given shareholders more voice to mitigate managerial self-interest. In some countries, such as the Netherlands or Denmark, the vote on remuneration policy is binding while in others (e.g. the UK and the US) it is mandatory but non-binding. At the EU level, the European Commission issued different recommendations on listed companies' say on pay since 2004, while more recently, its focus has shifted to the banking sector. In its corporate governance Action Plan of December 2012, the Commission announced plans to make legislative proposals in the course of 2013, so to enhance transparency and shareholder control over corporate executive remuneration.

\footnotetext{
${ }^{1}$ Opinions expressed in this paper are exclusively the authors' and do not necessarily reflect those of CONSOB.
} 
The academic literature has tested the effectiveness of such reforms in the UK and US contexts by analyzing both the determinants of shareholders' dissent and its effects on pay packages. As for the determinants, a key variable driving dissent has proved to be the level of CEO pay. Other variables that seem to be relevant are pay for performance sensitivity, the potential dilution in equity grants, firm risk and awarded perquisites (Alissa 2009; Carter \& Zamora 2009; Conyon \& Saldler 2010; Ertimur, Ferri \& Oesch 2011; Balsam \& Yin 2012; Kimbro \& Xu 2013). Regarding the ability of a negative vote to affect the level and structure of pay packages, the available evidence is mixed. While Conyon and Sadler (2010) find little evidence that dissent materially alters the subsequent level and design of CEO pay, Alissa (2009) finds that boards reduce excess compensation for firms whose CEOs have above the mean excess compensation. Similarly, Carter and Zamora (2009) find that boards selectively respond to disapproval from shareholders by curving excess salary bonus and stock option grants. Finally, Ferri and Maber (2009) find an increasing sensitivity of CEO pay to poor performance in firms experiencing a substantial voting opposition to the remuneration report; however they don't provide any evidence of an ex post change in the level of CEO pay.

A wider stream of literature has investigated the broader issue of shareholders activism, namely whether and how shareholders' voting choices matter. These scholars provide evidence of the increased effectiveness of some activism tools such as shareholders proposals and vote-no campaigns (Del Guercio, Seery \& Woidtke 2008; Ferri \& Sandino 2009; Ertimur, Ferri \& Stubben 2010; Cai \& Walkling 2011; Ertimur, Ferri \& Muslu 2011; Armstrong, Gow \& Larcker 2013). Before these group of studies, activism had only been evaluated through the presence of institutional investors in listed companies' capital (Brav, Jiang, Partnoy \& Thomas 2008, Klein \& Zur 2009).

Our contribution is the first analyzing the determinants of shareholders dissent on remuneration policy in a non-Anglo-Saxon context. In fact, corporate governance paradigms need to be framed within the particular economic context in which they are analyzed. Italy's and other continental EU member states' stock markets, as well as those of many fast-growing countries in Asia and Latin America, are characterized by listed companies which are most of the times under the control of one large shareholder, while institutional investors do not often play a key role (Bianco 2001, Bianchi, Bianco \& Enriques 2001, Bianchi \& Enriques 2005, Barca \& Becht 2001, Claessens \& Yurtoglu 2013, La Porta, Lopez-de-Silanes \& Shleifer 1999, Arslan \& Karan 2006, Kato \& Long 2006, Da Silveira, Leal, Carvalhal-da-Silva \& Barros 2008). Consequently, the market for corporate control is still underdeveloped and, similarly, the market for executives is also stuck. It follows that most of the remuneration packages are mainly fixed while variable components are less common than in other countries, namely the Anglo-Saxon (Croci, Gonenc \& Ozkan 2010, Barontini \& Bozzi 2011, Bebchuk, Fried \& Walker 2002, Thomas, 2004).

This manuscript is also a unique attempt to explain shareholders voting choices on remuneration policies by regressing them through a full set of corporate governance variables. These not only include independent variables measuring the level and structure of compensation and other standard control variables (as in the entire available literature on this topic) but also cover three key groups of regressors: the disclosure level of remuneration policy, ownership and control structure, the level of institutional investor activism. This information comes from a unique 
database that includes information coming from two different sources: the Italian Securities and Exchange Commission (CONSOB) dataset on Corporate Governance ${ }^{2}$ and the Listed companies' industry association (Assonime) data on boards and remuneration packages ${ }^{3}$. Such a complete set of listed companies' corporate governance information is hardly available in other countries. Consequently, Italy provides a perfect laboratory to experiment how say on pay works in a context of concentrated ownership.

Our analysis is based on a OLS regression model using a cross-section of data drawn from the 2012 shareholders' meetings. We also try to capture the determinants of high dissent (i.e. above average) through a logistic regression model. Our comprehensive dataset allows to come up with some original results explaining the determinants of dissent on remuneration policies in a nonAnglo-Saxon financial market.

Firstly, as expected, ownership concentration matters as the prevalence of controlling shareholder structures largely reduces dissent. In fact, our results show that dissent is higher in widely held firms and negatively correlated with the equity stake held by the largest shareholder. We interpret this result as a consequence of the reduced agency costs in controlled firms, where the high stake held by the controlling shareholder should reduce his incentives to deviate from value maximization. This result is also consistent with what observed in US and UK, where dissent has been shown to be negatively correlated with the stake held by insiders (namely, directors $)^{4}$. Interestingly, despite the negative correlation between ownership concentration and dissatisfaction, the level of dissent recorded in Italy is not particularly far from what found in other countries, where ownership is more disperse. Indeed, descriptive statistics show that in the first year of SOP implementation in Italy an average of $5.1 \%$ of the attending shareholders voted against (or abstained on) the company's remuneration policy. This result is slightly lower than the dissent recorded in the first year of mandatory say on pay in two Anglo-Saxon countries such as UK (where dissent varied between $7.9 \%$ and $16 \%$ depending on the sample used ${ }^{5}$ ) and US (where the level of recorded dissent is $\left.8.9 \%^{6}\right)$. Dissent in Italy is also in line with the one registered in Germany $(6.5 \%$ in $2010^{7}$ ), a country also characterized by high ownership concentration.

Secondly, we provide evidence that the way remuneration policy is disclosed is relevant in explaining the level of dissent. Shareholders favor the disclosure of much detailed information and are more likely to vote against if the remuneration report does not provide such information, especially for what concerns variable remuneration. In other words, the first implementation of say on pay in contexts with limited tradition on remuneration disclosure suggests that a preliminary condition for the market scrutiny to work is the existence and readability of information. This result is in line with what reported by the ISS (2013) Proxy Season Review, according to which the main reason for a negative vote recommendation in the 2012 AGMs of Italian companies was exactly

\footnotetext{
${ }^{2}$ Descriptive analysis of the data can be found in the Consob (2013) Corporate Governance Report on Italian listed companies.

3 Descriptive analysis of the data can be found in the Assonime-Emittenti Titoli (2013) Annual Report on the implementation of the Italian Corporate Governance Code.

${ }^{4}$ Morgan, Poulsen \& Wolf 2006; Conyon \& Sadler 2010; Cai \& Walkling 2011; Ertimur, Ferri \& Muslu 2011; Ertimur, Ferri \& Oesch 2013.

${ }^{5}$ Alissa 2009, Carter \& Zamora 2009, Conyon \& Sadler 2010, Ferri \& Maber, 2013.

${ }^{6}$ ISS, 2011.

${ }^{7}$ Eulerich, Rapp \& Wolf 2012.
} 
poor disclosure. However, it is interesting to note that when we turn to the analysis of the determinants of high (above average) dissent, disclosure does not matter anymore. As for the relation between dissent and the level of remuneration, our results confirm the empirical evidence available in UK and US, since dissent results to be positively correlated with CEO pay. This is particularly true in the case of high dissent, which result to be positively correlated with the level of compensation (both total and fixed), the amount of the equity part of the remuneration, excess compensation and which is increasing with remuneration quartiles. Hence, taken together, these results suggest that while low quality disclosure is likely to attract some negative votes, cases of high dissent are likely driven by other factors, mostly related to the quantum paid to directors.

Thirdly, dissent is largely due to the presence and engagement of institutional investors. We use two proxies of investor activism, the institutional investors' turnout at the shareholder meeting and the presence of directors appointed by minorities, both in the board and in the remuneration committee. As for institutional investors' turnout, we find that both the presence of Italian institutional investors at the AGM and the percentage of votes cast by foreign institutional investors increase the level of dissent. Moreover, the appointment of at least one director by minority shareholders facilitates an abstention or a negative vote, especially when the director sits in the remuneration committee. Indeed, minority directors may act as conduits of information to the market; in other words they may promote better disclosure thereby facilitating further engagement by active shareholders. These results are broadly confirmed when the drivers of high dissent are investigated. However, some differences emerge, since the probability of high dissent is only weakly correlated with the presence of minority directors while is much more affected by institutional investors' turnout.

Finally, dissent proves to be higher in larger firms (possibly because they are subject to closer scrutiny given that institutional investors invest prevalently in such firms) and lower in the financial sector, where the vote on the remuneration policy is binding. This last result is consistent with the insights arising from the existing literature, which argues that the binding/non-binding nature of the vote may affect shareholder incentives to vote in that they may exert self-restrain where the vote is binding and feel free to voice their disappointment where is not (Wagner \& Wenk 2013).

The rest of the paper is organized as follows. Section 2 describes the Italian regulatory framework, the related literature and develops our hypotheses. In Section 3 we show our dataset and explain the methodology. The empirical results are described in Section 4 while Section 5 concludes.

\section{Hypotheses development}

\subsection{The Italian regulatory framework}

Say-on-Pay (henceforth SOP) is a much debated issue, with numerous opponents and proponents. Those in favor of SOP argue that it is able to increase the sensitivity of executive pay to performance (Bebchuk, Friedman \& Friedman 2007, Ferri \& Maber 2012), enhancing transparency and accountability to shareholders. On the other side, opponents of SOP maintain that boards' role 
is to align their interests with those of the shareholders and that compensation plans already reflect this configuration. Also, they argue that shareholders are not able to understand and evaluate a compensation plan - with the risk of reducing board effectiveness - or may simply respond to special interests (Kaplan 2007, Gordon 2009). However, other scholars counter this view highlighting that the hypothesis whereby boards interests are structurally in line with those of shareholders is not always granted in reality. On the opposite - they add - excessive remuneration is not uncommon and several episodes of mispayment and fraud have been observed, resulting in greater shareholder awareness and activism. In this context, SOP has been advocated as a tool for all the shareholders to better voice their opposition to episodes of potential rent extraction (Jensen \& Meckling 1976).

The UK was the first country to introduce a system of enhanced remuneration disclosure and a mandatory SOP. In response to a wave of public concern on excessive pay that followed the privatization of public utilities, in 1995 the Greenbury Report introduced better disclosure of stockbased executive pay to ease investors' monitoring on managers. Later, with the Higgs Report, the perimeter of the disclosure system was widened to non-executive directors. The principles at the basis of self-regulation were then incorporated into hard law in 2002, when a comprehensive Directors' Remuneration Report (DRR) was mandated for UK listed companies, requiring wide disclosure of executive remuneration packages, including severance packages, together with a specific indication of all external advisors to the remuneration committee and an explanation of the criteria behind compensation choices (so-called remuneration policy). Furthermore, the new legislation envisaged a mandatory vote on the DRR at each AGM, but it was specified that no remuneration package could have been made conditional to it: so the vote was actually non-binding, resulting in a simple expression of confidence in the company's policy.

The favorable experience with say-on-pay in UK has caught the attention of several other jurisdiction, in particular the U.S. In January 2011, as mandated by the Dodd-Frank Act, the U.S. Securities and Exchange Commission (SEC) adopted rules that require all U.S. public companies to hold shareholder advisory votes on executive compensation, leaving up to their shareholders to determine whether this vote takes place every year, every two years or every three years. The DoddFrank regulatory novelty came after the recognition that under the previous regime - based on a non-mandatory SOP system - relatively few U.S. public companies had voluntarily included a SOP proposal for their shareholders to vote.

In the meantime, other countries such as Australia, Germany and Belgium, the Netherlands, Sweden, Norway and Denmark have also adopted similar SOP rules. For instance, the German VorstAG (Act for the appropriateness of executive board members' compensation), approved in 2010, envisages an optional (but widely implemented) system whereby listed companies' shareholders cast a non-binding vote on remuneration policies and on the packages awarded to executives. The Act also adds some provisions regarding the need for an appropriate relationship between remuneration and performance as well as on the minimum vesting period for stock options. Further, the supervisory board is given the power to adjust remuneration levels according to the company's situation. Another example is Belgium, where up to 2011 remuneration votes were only expressed on share-based compensation plans while the AGM approval of the remuneration policy was voluntary and uncommon. Under the new legislation (so-called Law on Corporate Governance 
and Executive Remuneration) all listed companies have later been subject to a mandatory nonbinding vote on remuneration reports to be casted every year (starting from 2012 AGMs). The law also provides for a mandatory and binding shareholders vote in case a company deviates from some best practices on variable pay. A country where a non-binding say on pay has been in place for long (i.e. since 2005) and has later been reinforced through a "two strikes" test is Australia. Under Amendments 250R(2) and 250U-V to the Corporations Act 2001, after a company gets two consecutive negative votes (accounting for more than $25 \%$ of its capital) to the remuneration report all board positions need to be confirmed by an ad hoc shareholders' resolution. Sweden also introduced binding shareholder votes on remuneration policies in 2006, as well as the Netherlands in 2004 and Denmark and Norway in 2007.

As for Italy, a new legislation was recently adopted in light of the two recommendations published by the EU Commission in 2004 and 2009 (i.e. 2004/913/CE and 2009/385/CE). It envisages better disclosure of executive remuneration through a mandatory document (so-called remuneration policy) that companies need to publish at least 21days before the AGM. The remuneration policy is articulated in two different sections and their contents have been defined by the Italian Stock Market Regulator (CONSOB) with an ad hoc regulation adopted on 23 December 2011. The first section illustrates the general principles guiding the way executives will be compensated in the following year. For example, it provides information on the relative importance of the variable and fixed components of directors' remuneration, the performance criteria on which any entitlement to variable components of remuneration is based, the linkage between remuneration and performance, the deferment periods with regard to variable components of remuneration, the vesting periods for share-based remuneration, the policy regarding termination payments and perks. The first section also dictates the procedures to be followed for the adoption and implementation of the remuneration policy, i.e. the composition and role of the remuneration committee and how independent experts - if any - have contributed to the policy's drafting. The second section breaks down the single items of remuneration packages - including parachutes - for each board member, the director general and for the top management overall and an adequate analytical representation of each single item. Disclosure obligations concern not only the sums received by the firm itself but also those received by subsidiaries and affiliates of the listed company. All the components of the remuneration package are split in several categories, such as fixed compensation, remuneration for the participation to board committees, non-equity variable compensation, perks, the fair value of equity remuneration, golden parachutes. Detailed information are given on the variable part of the remuneration, distinguishing between stock options, equity based compensation other than stock options and non-equity variable compensation.

The new CONSOB regulation on remuneration disclosure largely enriches the information available to the public under the previous regulatory regime. First, all the information on the remuneration general principles and procedures (the current first section) was missing. Secondly, data on awarded compensation were only partially available under the previous regime and have consequently been extended either introducing new information (e.g. the individual non-equity variable salary) and improving the quality of existing information (e.g. the need for each single equity-based compensation plan to be disclosed separately). 
The Italian reform also introduced new procedures for the approval of remuneration policies, by requiring all listed companies to cast a mandatory non-binding AGM vote on the first section of the policy, whose results need to be adequately disclosed to the public through the corporate website. In case the remuneration committee (or any other competent committee) expressed an opinion on the remuneration policy, this needs to be disclosed as well. These provisions are aimed at increasing the company responsiveness to shareholders and, in turn, their ability to voice their disagreement over pay practices, based on the assumption that market pressure is able per se to foster changes. A different approach was chosen by the Italian prudential regulators (i.e. the Bank of Italy and the ISVAP (now IVASS)), as remuneration policies of financial institutions and insurance companies receive instead a binding vote from shareholders. Further, both have introduced ad hoc disciplines for the banking and insurance sector remuneration, respectively, within the CRD and Solvency regulatory frameworks. The new rules are based on three main pillars: i) strengthened procedures for designing and approving remuneration policies; ii) guidelines on the way remuneration packages need to be structured; iii) disclosure duties, mostly in line with those envisaged for listed companies.

\section{2. $\quad$ Related studies}

The existing literature on say-on-pay (SOP) - aimed at investigating both the drivers of shareholders dissent and its effect on boards' behavior - only refers to the UK and US contexts.

With regard to the UK, Carter and Zamora (2009), using a sample of listed firms in the FTSE350 index over the period 2002-2006, find values of dissent ranging from a maximum of 7.9 percent in 2002 to a minimum of 3.4 percent in 2005. Dissent is positively related to the level of salary, the weakness in the pay-for-performance sensitivity in bonus pay and the potential dilution in equity grants, particularly stock options. As for the effects, they find that boards respond to negatives votes by reducing excessive salary and diluting stock option grants and by improving payfor-performance sensitivity. Using a sample of the largest UK companies in the FTSE350 from 2002 to 2008, Alissa (2009) finds that shareholders' dissatisfaction is increasing in excess compensation and that boards of firms whose CEOs have above the mean excess compensation respond to dissent reducing excess compensation. Moreover, the authors find that CEOs turnover is increasing in the level of dissent.

A more comprehensive study is performed by Ferri and Maber (2009), who analyze the impact of say on pay legislation using data of a large sample of UK firms before (2000-02) and after (2003-05) the introduction of the mandatory say on pay. They find no evidence of a change in the level and growth rate of CEOs pay after the introduction of the new legislation. However, they find an increase in the sensitivity of CEOs pay to poor performance, especially in firms experience substantial voting opposition against the remuneration report and in firms with an excessive level of CEOs pay before the adoption of say on pay, regardless of voting dissent.

Differently from previous studies, Conyon and Sadler (2010) investigate shareholder voting choices not only with reference to the director remuneration report but also on all other proposals (e.g. the resolutions to elect directors) and evaluate how director remuneration report voting differs from that on other items. First, they find low levels of dissent on CEO pay: less than 10 percent of 
shareholders abstain or vote against the mandated director remuneration report resolution. Secondly, shareholders are more likely to vote against the remuneration report compared to other non-pay resolutions such as the election of a director. Moreover, dissent is higher in firms with high CEOs pay. As for the effects, they find little evidence that CEOs pay is lower in firms that previously experienced high level of dissent and that dissent materially alters the subsequent level and design of remuneration packages.

With reference to the US, Balsam and Yin (2012) study how companies and shareholders respond to the introduction of SOP by examining either the changes, if any, companies make in their executive compensation programs in advance of the initial say on pay vote (i.e. in 2010) and the determinants of say on pay in its first application in 2011. In line with their intuition, the authors find that firms modified their compensation packages in 2010 by reducing CEO compensation, especially those firms that overpaid their CEOs in the previous year. Moreover, they show that shareholder voting on say-on-pay is not random, but systematically related to compensation practices: shareholders are more likely to vote against executive compensation when the firm pays a large absolute amount of CEO compensation, has a large increase in CEO compensation from the prior year or has a larger amount of compensation that cannot be explained by economic factors. Among the components of the compensation package, shareholders are more likely to vote against the compensation package when they contain "other compensation", namely perquisites, such as private jets or country club memberships.

Kimbro and $\mathrm{Xu}$ (2013) examine the results of the first two years (2011 and 2012) of shareholders' votes on remuneration policy for listed companies included in the Russell 3000 index. They find that SOP reject votes are associated with lower returns, higher institutional ownership and CEO compensation. Moreover, the authors find that dissent is also sensitive to firm risk and accounting quality, being increasing in the level of volatility and in the level of abnormal accruals. As for the effects of negative votes, the analysis suggests that shareholders voting rights could be an effective mechanism of corporate governance since boards react to dissent by reducing the level of excessive compensation.

A different analysis is performed by Ertimur, Ferri and Oesch (2011), who focus on the effect of proxy advisors' recommendations (Institutional Shareholder Services - ISS - and Glass Lewis \& Co. - GL) on shareholder votes, stock prices and firm behavior in the context of mandatory say on pay votes. They find that proxy advisors are more likely to issue an against recommendation in the case of firms with poor performance and higher levels of CEO pay, but rather than following a "one-size-fits-all" approach, they take into account firm-specific circumstances. Moreover, analyzing the association between the SOP-related content in proxy advisors' report and shareholder vote, they find that proxy advisors' recommendations are the key determinant of voting outcome: a negative recommendation from both ISS and GL is associated with $38.3 \%$ more votes against the compensation plan.

Finally, a few papers have analyzed the empirical effects of shareholder power on firm value by studying the market reaction to the introduction of the say on pay legislation. Cai and Walkling (2009) study how the US market responded to the approval of the House Say-on-Pay Bill on April 2007. They find that the market reaction was significantly positive for firms with questionable pay practices (namely firms with high abnormal CEO compensation and with low pay-for-performance 
sensitivity), which may particularly benefit from say on pay. However, the authors also analyze activist-sponsored say-on-pay proposals over the period 2006-2008 and find that targeted firms are not those with excessive CEO pay, poor governance, or poor performance, but are mainly large companies. In addition, most of these proposals were sponsored by labor-unions with small stock holdings in the company and the announcement of union-initiated proposals was followed by a reduction of stock prices and received low support from other shareholders. The authors conclude that say on pay may create value for companies with inefficient compensation but can destroy value for others. Wagner and Wenk (2013) assess the stock market reaction to the unexpected announcement of a prospective change in Swiss law consisting in the introduction of a binding vote on remuneration policy. They find that 70 percent of Swiss listed companies responded with negative abnormal stock returns to such announcement. However, careful analysis of the crosssectional variation in reactions shows that shareholders rationally anticipate that say on pay comes with benefits and costs, reacting more negatively when the costs are likely to outweigh the benefits. Indeed, the impact is particularly negative in firms where specific investments by CEOs are more difficult or more important to secure while it's more positive in firms where alignment between shareholders and managers is poor.

Other studies have analyzed more in general the topic of shareholders voting on remuneration in the US, focusing on non-binding shareholder proposals related to executive pay or on vote-no campaigns (Morgan, Poulsen \& Wolf 2006; Del Guercio, Seery \& Woidtke 2008; Ferri \& Sandino 2009; Ertimur, Ferri \& Stubben 2010; Ertimur, Ferri \& Muslu 2011; Armstrong, Gow \& Larcker 2013). Some of these studies confirm the finding that shareholders proposals target firms with higher levels of CEO total pay (Ferri \& Sandino 2009; Ertimur, Ferri \& Stubben 2010; Ertimur, Ferri \& Muslu 2011). In addition, Ertimur, Ferri and Muslu (2011) show that proposals aimed at affecting the pay setting process receive the highest voting support, followed by proposals aimed at influencing the output of the pay setting process and finally by those aimed at affecting the objective of the pay setting process. As for board responsiveness to such proposals, many studies find that the likelihood of implementation is increasing in the degree of shareholder pressure (Ferri \& Sandino 2009; Ertimur, Ferri \& Stubben 2010; Ertimur, Ferri \& Muslu 2011). Del Guercio, Seery and Woidtke (2008) find a variety of supportive evidence, including operating performance improvements and abnormal disciplinary CEO turnover, indicating that campaigns induce boards to take actions in shareholders' interests. Differently, Armstrong, Gow \& Larcker (2013) find little evidence that either lower shareholder voting support for, or outright rejection of, proposed equity compensation plans leads to decreases in the level or composition of future CEO incentivecompensation, suggesting that shareholder votes have little substantive impact on firms' incentivecompensation policies.

Our study differs from prior studies in two main aspects. First, we are the first investigating how say on pay works in a non-Anglo-Saxon country, like Italy, where firms are usually strongly controlled by one or more shareholders. Secondly, leveraging on a unique dataset, we look at the determinants of dissent by considering a wide range of possible regressors that allow us to evaluate how dissent is linked to multiple variables related to the ownership and control structure, the board composition, institutional investors activism, the level and the structure of remuneration and the level of remuneration policy disclosure. At this stage we are still not able to investigate the effects 
of the introduction of say on pay in Italy as the new regulation came into force only in 2011. Future research will address this topic.

\subsection{Research hypotheses}

We analyze shareholders' voting on the remuneration policy of Italian listed firms. According to Italian rules, a remuneration report (RR) is prepared by the board and is submitted to shareholders' vote at the Annual General Meeting (AGM). The RR is composed of two sections: the first section explains ex-ante the company's policy on future directors' remuneration (and the procedures used to adopt and implement it), while the second reports detailed ex-post information on the remuneration paid to individual board members and general managers in the last financial year. Shareholders vote only on the former, i.e. they are not formally entitled to express their "voice" on the sums actually paid to the company executives.

CONSOB regulation requires disclosure of the main features of the remuneration policy (including the relative weight of the fixed/variable components of directors' remuneration, the short- vs. long-term nature of variable pay, a description of the performance targets adopted by the company, etc.). Since the structure of the remuneration policy may differ significantly across companies, no standardized disclosure format is provided for the first section of the RR, thereby leaving considerable room to individual firms choosing more or less explicit disclosure policies. We hypothesize that the quality of the information actually disclosed by the company may crucially influence the voting outcome, in the sense that shareholders prefer the disclosure of detailed information and are more likely to vote "against" if the remuneration policy does not meet a minimum quality standard. Disclosure quality looks particularly important for the components of variable remuneration, since: a) anecdotal evidence shows that dissent has been particularly high in cases where executives received "outrageously high" remuneration; b) cash bonuses and equitybased (together with severance) pay are the main channels through which executives may receive high remuneration; c) variable pay is determined according to technically complex formulae, and detailed disclosure in this matter seems particularly important for investors. Actually, ISS (2013) reported that the main reason for a negative vote recommendation in the 2012 GM's of Italian companies was poor disclosure, especially on performance criteria both for short- and long-term variable remuneration. This leads us to our first hypothesis.

Hypothesis 1. Shareholder voting dissent is negatively correlated to the quality of disclosure provided in the first section of the Remuneration Report, particularly in the field of variable remuneration.

Even though shareholders are formally entitled to vote only on the first section of the remuneration report, they may use their vote to convey dissatisfaction with the level and/or structure of past executive remuneration, resulting from the second section of the RR, or available otherwise (e.g. in cases where severance payments were recently made as a consequence of CEO turnover). Previous literature has clearly shown that shareholder dissent on SOP votes increases with directors' remuneration (Carter \& Zamora 2009; Conyon \& Sadler 2010; Ertimur, Ferri \& Oesch 2013; Kimbro \& Xu 2013). Shareholders' dissent (support) is also positively (negatively) correlated with remuneration in the case of management (shareholder) proposals on remuneration 
issues (see Morgan, Poulsen \& Wolf 2006 and Ertimur, Ferri \& Muslu 2011, for management and shareholder proposals, respectively). This relation has generally proved to be robust to alternative definitions of remuneration (e.g. as total or excess remuneration, defined as the residual from an expected compensation model that controls for standard economic determinants of compensation: Alissa 2009).

The relation between remuneration and shareholder dissent need not be linear: actually, dissent could be particularly pronounced where CEO remuneration is perceived to be extremely (or “outrageously") high. Previous literature (Cai \& Walkling 2011; Thomas, Palmiter \& Cotter 2012; Ertimur, Ferri \& Oesch 2013) has tried to capture these effects looking at remuneration quartiles (with dissent expected to be particularly high in the top remuneration quartile). Our second hypothesis may then formulated as follows.

\section{Hypothesis 2. Shareholder voting dissent is negatively correlated to CEO remuneration.}

Dissent is higher where CEO remuneration is particularly high (in the top quartile).

Dissent may also be correlated to CEO remuneration structure. This point is controversial. On one hand, variable remuneration should align managerial incentives with shareholders' interests. Therefore, investors should prefer the \% stake of variable remuneration (variable/total remuneration) to be higher, implying that dissent should be negatively correlated to such stake. On the other hand, shareholder dissent seems to be higher in resolutions concerning variable components of remuneration (Conyon \& Sadler 2010); in general, dissent with management compensation proposals seems negatively related with the \% of non-salary compensation (variable + prior equity: Armstrong, Gow \& Larcker 2013); actually, "outrageously" high total remuneration is typically driven by a high value of variable pay. Consequently, it is difficult to formulate ex-ante hypotheses about the expected sign of this relation.

To the best of our knowledge, our paper is the first attempt to study SOP in a context (Italy) where firm ownership is concentrated. Ownership structure may influence shareholders' voting in a number of ways: this holds true also as far as SOP is concerned. In principle, higher ownership concentration should be associated with higher incentive alignment (lower agency costs): controlling blockholders may alternatively be the firm owner-managers (as in the classical JensenMeckling 1976 example) or perform a role of delegated monitors toward a professional manager. In both cases, the higher their equity stake, the lower their incentives to deviate from value maximization (directly, through perk consumption or higher remuneration, in the former case; indirectly, through lower monitoring effort toward the manager, in the latter case). Hence, lower dissent on the remuneration policy is expected where ownership is concentrated. Previous literature (Morgan, Poulsen \& Wolf 2006; Conyon \& Sadler 2010; Cai \& Walkling 2011; Ertimur, Ferri \& Muslu 2011; Ertimur, Ferri \& Oesch 2013) has confirmed this theory in anglo-saxon countries, where ownership is typically dispersed and concentration is measured in terms of the equity stake held by insiders (i.e. directors).

In Italy, firm ownership is often concentrated in the hands of a controlling shareholder. This allows us to distinguish between various possible situations. In general terms, we hypothesize that the same effect observed in Anglo-Saxon countries should take place also in a concentrated setting. Incentive alignment should be higher (and, hence, dissent on remuneration policy should be lower) 
where a controlling shareholder is present; dissent should further decrease as the controlling shareholder holds a higher equity stake, thereby internalizing agency costs. Barontini \& Bozzi (2011) show that board compensation in Italian firms is negatively correlated with ownership concentration. The monitoring function of controlling shareholders may, however, be hampered by increasing separation of ownership from control, via dual class shares and/or pyramiding (Bebchuk, Kraakman \& Triantis 2000; Faccio \& Lang 2002; Nenova 2003). Consequently, we expect incentive alignment to decrease (and dissent to increase) where the wedge between cash-flow rights (CFR) and voting rights (VR) is higher. Our third hypothesis follows.

Hypothesis 3. Shareholder voting dissent is higher in widely held firms and is negatively correlated with the equity stake held by the largest shareholder. Dissent is higher where the CFR-VR wedge is higher.

Controlling shareholders may be different in nature: in Italy, they are often members of a family (possibly including the founder of the firm and/or his heirs); many firms are under the control of the state or other public entities; in other cases, listed firms are controlled by financial institutions or private equity funds; finally, they may be controlled by a coalition of these subjects (Bianchi \& Bianco 2007). In general, different classes of controlling shareholders may have different incentives to monitor management compensation. Barontini and Bozzi (2011) show that board compensation tends to be higher in Italian family firms, especially if board members are also members of the controlling family, signaling possible entrenchment; the opposite is true for stateowned firms, where board compensation tends to be lower. While this might induce higher dissent on the remuneration policy in family firms, it must be observed that differences in remuneration may be induced by (unobservable) differences in quality of board members: this makes the expected sign unclear. However, we still deem important to test if dissent varies with the identity of the ultimate shareholder.

Directors' remuneration is a well-known target for investor activism in the US (Johnson \& Shackell 1997; Gillan \& Starks 1998 and 2007; Morgan, Poulsen \& Wolf 2006; Ertimur, Ferri \& Muslu 2011). In Europe, the room for active investors either to vote on compensation-related management proposals or to submit their own proposals to the shareholders' meeting is influenced by a number of country-specific rules (Barontini, Bozzi, Ferrarini \& Ungureanu 2013), and has traditionally been more limited. However, activism looks on the rise (Renneboog \& Szilagyi 2013), especially in countries which have adopted SOP legislation. Italy is no exception in this regard: active investors have apparently taken advantage from a number of reforms, which have made the Italian regulatory framework, once notoriously activist-repellant, much more investor-friendly (Belcredi \& Enriques 2013). We hypothesize that dissent is higher in companies targeted by active investors.

Active investors usually prefer to engage with listed companies privately. Only after contacts behind the scenes proved ineffective, they start public initiatives, which may then culminate in a shareholder proposal and/or in a campaign against management proposals at the shareholders' meeting. Since private contacts are substantially unobservable, previous literature on activism usually concentrated on active investors buying a "relevant" equity stake (i.e. subject to public disclosure obligations: see, for the US, Brav, Jiang, Partnoy \& Thomas 2008; Klein \& Zur 2009; for Europe, Croci 2007) or on campaigns involving a confrontation with management at the 
shareholders' meeting. This seems particularly appropriate for issues - including SOP - involving a shareholder vote. Previous literature shows that dissent is positively correlated with the equity stake held by institutional investors (Johnson, Porter \& Shackell 1997; Ertimur, Ferri \& Muslu 2011; Ertimur, Ferri \& Oesch 2013; Kimbro \& Xu 2013), particularly those which may be clearly identified as active or, at least, as "independent" (Cai \& Walkling 2011), i.e. mutual and pension funds which are not interested in other business opportunities with the target firm.

Institutional ownership may be influenced by portfolio strategy considerations: institutional investors with strong fiduciary responsibilities tend to invest in stocks that are viewed as prudent investments (Del Guercio 1996; Parrino, Sias \& Starks 2003) and also in companies with better governance quality (Barucci \& Falini 2005; Bianchi, Ciavarella, Novembre \& Signoretti 2010; Chung \& Zhang 2011). Consequently, turnout of institutional investors at the AGM seems a better proxy than mere ownership for an institution's potential willingness to actively engage with the target firm. Actually, the decision to show up at the shareholders' meeting is far from obvious, given the implied transaction costs.

A second, peculiar channel investors may choose to actively engage with listed firms is provided by Italian legislation, namely slate voting: minority shareholders may present a slate of candidates for the board of directors (since 2007; since 1994 in privatized companies, where at least $20 \%$ of the board seats are reserved for minority representatives) and have at least one of their candidates appointed to the board, even in the presence of another slate gaining a higher number of votes (Belcredi, Bozzi \& Di Noia 2013). This creates an opportunity for active investors to monitor corporate decisions directly at the board level, through the appointment of minority directors, who usually qualify as "independent". The association of Italian mutual funds (Assogestioni) has been particularly active in coordinating the efforts of (both domestic and foreign) institutional investors in this field (Belcredi \& Enriques 2013). It has been argued that the presence of minority directors may induce better compliance with best practices (Bianchi, Ciavarella, Novembre \& Signoretti 2010), thereby reducing the risk of expropriation for minority shareholders. Available anecdotal evidence shows that, at least in some cases, minority directors have had a positive influence on corporate decisions (Belcredi \& Enriques 2013). Even when they are not able to block potentially harmful decisions, minority directors may promote a better disclosure of their economics, thereby facilitating further engagement by active shareholders. A separate measure of investor activism may therefore be founded on the presence of minority directors - and, in particular, of directors drawn from slates submitted by mutual funds coordinated by Assogestioni - on the board (and/or in the Remuneration Committee, recommended by the Italian Corporate Governance Code: Johnson \& Shackell (1997) argue that the Remuneration Committee composition may be relevant for subsequent shareholder voting). The previous discussion leads us to our last hypothesis.

H4. Shareholder voting dissent is higher where investor activism is stronger. In particular:

H4.1. Dissent is higher where the turnout of institutional investors (especially mutual, pension and hedge funds) is higher.

H4.2. Dissent is higher where minority directors (and, especially, directors drawn from minority slated proposed by Assogestioni) sit on the board and/or in the Remuneration Committee). 


\section{Methods}

\subsection{Sample selection and descriptive statistics}

We investigate shareholder voting behavior using data from the 2012 Annual General Meetings, when SOP was implemented for the first time (except in financial firms, as noted above). Our initial sample comprised 251 companies (i.e. all companies listed on the Italian Stock Exchange). Data on shareholder votes (dissent) and institutional investor turnout were handcollected from the official GM minutes (published on the company websites according to CONSOB regulation). Dissent is measured as the percentage of negative votes on the remuneration policy cast at the General Meeting (i.e. (Against + Abstain)/Total votes, since abstentions are - actually counted as negative votes according to Italian legislation). We ignore 5 cooperative banks (plus one insurance company), since they adopt a one-head-one-vote regime, leading to clearly noncomparable voting outcomes. After dropping firms with missing or incomplete data, we end up with a sample of 226 companies.

Information on the remuneration policy and directors' remuneration was hand-collected from the companies' Remuneration Reports (also available on the company websites). Accounting and stock market data come from Datastream-Worldscope. The rest of our data are drawn partly from the CONSOB database (ownership structure, CEO age), partly from the database underlying the Assonime-Emittenti Titoli Annual Report (2013) on the implementation of the Italian Corporate Governance Code (characteristics of the Board and of the Remuneration Committee, CEO identity and turnover). Summary statistics are reported in Table 1.

\section{Insert Table 1 about here.}

Italian listed companies are usually small or medium enterprises: the average (median) firm has total assets around EUR 15,460 (450) million and a market capitalization of EUR 1,400 (122) million. The single largest company (Eni) accounts for around $20 \%$ of total market cap; the first 5 (10) companies account for around $45 \%$ (62\%) of the aggregate. Ownership is typically concentrated: on average, the single largest shareholder holds a $48 \%$ stake (in terms of cash-flow rights, and a $51 \%$ stake in terms of voting rights). Around $60 \%$ of Italian listed firms are under the control of a family, holding on average a $56 \%$ block; $10 \%$ of the companies in our sample are controlled by the State or by other public entities; $15 \%$ are controlled by a coalition of different subjects; $6 \%$ are widely held (and another $4 \%$ are controlled by widely held companies). Shareholder agreements are present in around $19 \%$ of the cases. The recourse to control-enhancing mechanisms (dual class shares and pyramids) has been quite limited in recent years: the average wedge between voting and cash-flow rights (as defined below) is around 3.2\%.

The average (median) CEO total compensation (fixed + variable, inclusive of the equitybased component) resulting from the RR's submitted to shareholders' vote in 2012 was around 1.4 
million (670 thousand) Euro. The amounts reported include, in line with CONSOB regulation, all sums received by the CEO, both in the listed company and in its subsidiaries and affiliates). Total remuneration is extremely variable, from a few thousand to 22 million Euro (Mr. Marco Tronchetti Provera, in Pirelli).

Average dissent in Italy was $5.1 \%$ of votes cast in 2012, i.e. somewhat smaller than the dissent recorded in the first year of mandatory SOP in Anglo-Saxon countries, where ownership is dispersed. The average dissent in the US (in 2011) was 8.9\% (ISS 2011; Balsam and Yin (2012) using a smaller sample, find a higher average dissent, between 10 and 20\%, depending on how abstentions are considered). In the UK, the average dissent in the first SOP season (2003) varied between $7.9 \%$ and 16\%, depending on the sample used (Alissa 2009; Carter \& Zamora 2009; Conyon \& Sadler 2010; Ferri \& Maber 2013). Shareholder dissent in Italy was quite similar to that recorded in Germany (6.5\% in 2010, according to Eulerich, Rapp \& Wolf 2012), a country characterized also by concentrated ownership, where listed firms were allowed since 2010 to adopt non-binding SOP on a voluntary basis (a regime not dissimilar from pre-Dodd-Frank regulation in the US).

Differences in voting outcomes across countries should not be exaggerated: situations of "high" dissent were uncommon everywhere. We counted 17 companies in Italy (accounting for $7.5 \%$ of our sample) where dissent was $>20 \%$ of votes cast: the frequency of such cases is lower than in the US (14.6\%, Kimbro \& Xu 2013) and in the UK (26.5\%, Ferri \& Maber 2013), and similar to that reported for Germany, where dissent exceeded $25 \%$ of the votes cast in $6.7 \%$ of the firms (Eulerich, Rapp \& Wolf 2012). The remuneration policy/report prepared by the board failed to reach a majority only on rare occasions: we counted only four such cases (1.8\% of the aggregate) in our Italian sample (Cape Live, Impregilo, Retelit and Screen Service). This compares with 38 firms in the US (1.6\% of the cases for which voting data were available: ISS 2011), $6(2.1 \%)$ in the UK (Ferri \& Maber 2013) and, finally, 1 case (1.1\%) in Germany (Eulerich, Rapp \& Wolf 2012). Interestingly, in Italy negative majority votes always took place within a complex corporate governance framework: Cape Live had recently sought protection from creditors under Italian bankruptcy law, and its shareholders deliberated - at the same meeting when the RR was voted down - to sue 4 former board members for liability. Screen Service, formerly controlled by Cape Live as well, was at the center of a battle for control between Opera (a private equity fund) and Permian (a US-based activist hedge fund, which had previously targeted other telecom companies in Italy); the whole board resigned during the shareholder meeting and the RR received negative votes by an ample majority (88\%) of shareholders, which included the largest individual shareholder (Opera). In Impregilo and Retelit the negative vote may also be seen as part of a battle for the company control between different groups of relevant shareholders (the Libyan Post \& Telecom Company and the competitor Sirti, in the telecom company Retelit; the incumbent Gavio family and the competitor Salini group, in the general contractor Impregilo).

\subsection{Shareholder voting model}

To test our hypotheses we run an OLS regression model using a cross-section of data drawn from the 2012 shareholders' meetings. More specifically, we regress shareholder dissent on four 
different sets of independent variables, capturing various specifications of the hypotheses formulated above. Our model is the following:

$$
\begin{aligned}
& \left.{\text { Shareholder } \text { Dissent }_{i j}=\alpha_{i}+\beta_{i j}\left(\text { Disclosure }_{i j}\right)+\beta_{i k}(\text { CEO Remuneration }}_{i k}\right)+\beta_{j l} \\
& \left(\text { Ownership }_{i l}\right)+\beta_{\text {im }}\left(\text { Activism }_{i m}\right)+\beta_{\text {in }}\left(\text { Controls }_{i n}\right)+\varepsilon_{i}
\end{aligned}
$$

The dependent variable in the regressions is calculated as the negative votes ("against" + "abstain") expressed by shareholders on the 2012 remuneration policy, as a percentage of total votes cast. The independent variables are calculated as follows. First, we construct a scoring variable based on the narrative of the Remuneration Report, capturing the quality of information disclosed about what seems to be the crucial issue in the eyes of institutional investors and proxy advisors, i.e. the structure of variable board remuneration (cash bonuses + equity and/or stock options). We built this variable as the sum of six different $1 / 0$ dummy variables, capturing a separate aspect of disclosure each, spanning from the expected relative weight of fixed/variable remuneration to the disclosure of a cap to variable remuneration, the performance parameters variable remuneration is linked to, etc. (the precise definition of all variables is reported in the Appendix). Of course, this scoring model is calculated only for the subset of 169 companies where a variable remuneration was granted to board members (including the CEO). In the remaining 54 companies for which data are available, board members received only a fixed remuneration (although, in a number of cases, variable remuneration was provided for employees).

The second set of variables captures the amount and structure of CEO remuneration in 2011 (as reported in the RR's submitted to shareholders' vote in 2012). We consider fixed and variable, cash and equity-based pay, both in absolute value and in \% terms; following previous literature, we also consider quartiles and excess remuneration (i.e. residuals from an expected remuneration model accounting for the main determinants of compensation). The CEO is identified on the basis of the information reported in Corporate Governance reports.

Our third set of variables describes the ownership structure of the company. We calculated both Cash-Flow Rights and Voting Rights (as in Faccio \& Lang 2002) of the ultimate shareholder and used the wedge between CFR and VR as a measure of separation of ownership from control. We also consider the identity of the ultimate shareholder. Consistently with previous literature, we classify firms according to the identity of the ultimate shareholder, which may alternatively be: a) a family; b) the State or another public entity; c) a private equity fund; d) a coalition of various subjects; d) a widely held company. If no shareholder holds more than $10 \%$ of voting rights, the company is classified as widely held.

Our final set of variables includes various proxies for investor activism. As noted above, we measure activism through: a) the turnout of institutional investors (with a particular attention for "independent" institutions, such as mutual, pension and hedge funds, both domestic and foreign) at the GM where shareholders vote on the remuneration policy: we measure turnout, alternatively, in terms of a 1/0 dummy (capturing whether some institutional investor was present at the GM), and of the votes they actually cast. At least one institutional investor was present in $73 \%$ of the shareholders' meetings. Their average turnout, in terms of the \% votes commanded by institutions at the AGM was $6.9 \%$ (2.4\%). Foreign funds account for around $2 / 3$ of the votes commanded by institutional investors: their average turnout is $4.4 \%$; however, their median turnout is a much lower 
$0.4 \%$, showing that their presence is concentrated in blue chips; b) a set of dummy variables capturing the presence of minority directors (with a particular attention for those drawn from slates submitted by institutional investors under the leadership of Assogestioni, the association of Italian mutual funds) either on the board or Remuneration committee. Table 1, Panel B shows that minority (Assogestioni) directors are present in 40\% (6\%) of the companies in our sample; in $24 \%$ $(5 \%)$ of the cases, at least one of them is a member of the Remuneration committee.

Our shareholder voting regressions include a set of control variables. We control for a number of firm characteristics which might potentially affect our results, including firm size (measured as the logarithm of total assets), Tobin's Q and the Market/Book value of Equity (as proxies of a firm's growth opportunities), the standard deviations of stock returns (a proxy for risk), ROA and three-year annualized stock returns (proxies for a firm's accounting and market performance, respectively) ${ }^{8}$. We also include a $1 / 0$ dummy variable capturing whether the firm is a financial (a bank or an insurance company) or a non-financial firm.

While industry dummies are common in the SOP literature, this variable is of considerable import in Italy, where the presence of different regulatory regimes provides an opportunity to test their effects probably unique in the world. Actually, while votes on remuneration policy are generally non-binding, they are binding in financial firms, which are also subject to a number of specific rules (in force since 2009 and repeatedly amended), including additional disclosure obligations and the mandatory adoption of specific remuneration structures. Consequently, the financial/non financial dummy may be read as a "regulation" variable in Italy". It has been argued (Yermack 2010; Levit \& Malenko 2011; Goex, Imhof \& Kunz 2012) that the binding/non-binding nature of the AGM vote may have a non-trivial effect on shareholder incentives to vote (and also on the voting outcome). In particular, shareholders may be expected to exert self-restraint where the vote is binding, whereas they may feel freer to voice their possible discontent where the vote is nonbinding (e.g. since hold-up problems may arise when shareholders have too much power: Wagner \& Wenk 2013). For these reasons (and also since financial firms are likely to disclose information of better quality as a consequence of additional regulation) we expect a lower voting dissent in the financial sector.

Table 2 presents a correlation matrix between the main variables used in our analysis.

\section{Insert Table 2 about here.}

Some facts are immediately apparent. First, the various components of CEO remuneration are highly correlated with each other, and with firm size. Large companies simply pay their CEOs more; this is true for both fixed and variable pay (and also for both cash and equity compensation).

\footnotetext{
${ }^{8}$ We choose 3-year returns to avoid recent events unduly influencing our results; we refer, for instance, to corporate events, such as the proxy fights mentioned above in the cases where the board proposals failed to reach a majority. Three-year returns are used rather frequently in the related literature (e.g. Conyon \& Sadler 2010; Ertimur, Ferri and Muslu (2011) use two-year returns).

${ }^{9}$ In a handful of cases, we had to revise the official classification provided by the Italian Stock Exchange on the basis of additional information about the voting regime drawn from the GM minutes.
} 
Second, the turnout of institutional investors (in particular, of foreign funds) is strongly, positively correlated with firm size, implying that monitoring and engagement will likely be higher in larger companies. Third, when minority directors sit on the board, one of them (at least) is frequently a member of the Remuneration committee; the same happens for directors drawn from Assogestioni slates. The presence of Assogestioni directors is also correlated with institutional investors' turnout (indirectly confirming that they may be considered as different proxies for the same underlying phenomenon, i.e. investor activism) and also with firm size (though here the correlation is somewhat weaker), implying that Italian mutual funds tend to concentrate their governance efforts on blue chips. The same is not true for minority directors in general. While these facts can hardly be deemed surprising, they have clear methodological implications for the following analysis: caution will be needed to avoid collinearity problems.

\subsection{High-dissent (logistic specification)}

To further test our hypotheses we repeat our analysis using a logistic regression model, trying to capture the determinants of "high" dissent. More specifically, we regress a 1/0 dummy variable, capturing the probability that shareholder dissent is high (i.e. above a pre-defined threshold) on the same sets of independent variables used in the previous analysis. Our new model is the following:

$$
\begin{aligned}
& \left.{\text { High Dissent } \text { Dummy }_{i j}=\alpha_{i}+\beta_{i j}\left(\text { Disclosure }_{i j}\right)+\beta_{i k}(\text { CEO Remuneration }}_{i k}\right)+\beta_{j l} \\
& \left(\text { Ownership }_{i l}\right)+\beta_{\text {im }}\left(\text { Activism }_{\text {im }}\right)+\beta_{\text {in }}\left(\text { Controls }_{i n}\right)+\varepsilon_{i}
\end{aligned}
$$

High/low dissent is defined according to whether the sum of negative votes and abstentions (in percentage terms) is above/below the sample average (5.1\%). Since dissent is asymmetrically distributed (dissent was above the sample average in 55 companies), this is substantially equivalent to comparing the top dissent quartile vs. the rest of the sample.

\section{Results}

\section{1. $\quad$ Results for the shareholder voting model}

Table 3 contains the results of a preliminary analysis, conducted regressing shareholder dissent on a set of firm characteristics (later to be used as control variables). First, as expected, dissent is significantly lower in financial firms. Amongst other firm characteristics, the percentage of negative votes appears to be correlated only with firm size (measured by the log of total assets), while the other variables in the regressions are not statistically significant. Using lagged variables has virtually no impact.

Insert Table 3 about here. 
Some results deserve a specific comment. Contrary to what happens in the US (Ertimur, Ferri \& Oesch 2013; Kimbro \& Xu 2013) and in the UK (Conyon \& Sadler 2010), where shareholder dissent is strongly, negatively correlated to firm performance, in Italy the negative votes on the remuneration policy are - apparently - correlated neither with ROA (whose coefficient has the correct - negative - sign but is not statistically significant), nor with stock returns. Puzzling as this may be, this evidence shows that investors undoubtedly consider other factors as more relevant for their decisions on SOP issues. Furthermore, shareholder dissent is positively (and significantly) correlated with firm size. This result is in line with our expectations. As already noted, many Italian listed firms are small- or micro-cap companies, and mutual and pension funds invest prevalently in blue chips (Belcredi, Bozzi \& Di Noia 2013). This result is robust to alternative regression specifications, and shows that large firms are "different" in Italy, in that they are subject to closer scrutiny (especially by institutional investors; see also Table 2). This finding contrasts with those emerging from the US literature (both Ertimur, Ferri \& Oesch 2013 and Kimbro \& Xu 2013 find a negative correlation of dissent with log market cap, used as a proxy for firm size), while the UK literature gets mixed results (Alissa 2009 and Carter \& Zamora 2009 obtain a weak, negative correlation with log total assets; Conyon and Sadler (2010) find a positive though insignificant - correlation with log market cap).

Table 4 shows the results when disclosure quality is included in the analysis. The disclosure index has the correct (negative) sign, showing that dissent is lower in companies providing investors with more detailed information about variable remuneration. However, the relation is not statistically significant. The disclosure of individual items considered by our scoring model seems, also, hardly relevant. On the opposite, results are quite strong for the "low disclosure" dummy, implying that investors tend to vote against the remuneration policy only when transparency is very low. We interpret this evidence as broadly consistent with Hypothesis 1: dissent is negatively correlated with the quality of disclosure. However, the relation is statistically significant only when disclosure is very low.

\section{Insert Table 4 about here.}

Table 5 reports the results of our regressions on CEO compensation. CEO compensation has the correct (positive) sign, showing that dissent is higher in companies paying their CEOs more. The relation, however, is not significant if firm size is included in the analysis. When firm size is excluded to avoid collinearity, CEO total compensation becomes statistically significant but, still, the relation is not particularly strong ( $\mathrm{p}$-value around 7\%). The picture is quite similar when individual components of CEO pay are considered in turn; as predicted, the sign is positive, but the relation is significant only for equity-based pay, possibly implying that stock-options and -grants give rise more frequently to remuneration payments considered "outrageous" by investors ${ }^{10}$.

\footnotetext{
${ }^{10}$ Furthermore, the statistical significance of results is negatively affected by the features of the fair value measure adopted by the Italian regulation. Actually, the value of equity-based pay to be disclosed in the Remuneration Report is the fair value of stock-options, -grants, and other instruments at the grant date, as expensed in the financial statements according to IAS-IFRS. The choice of an accounting-based measure guarantees comparability of RR's with financial data and, and also across firms/years. However, comparability comes at a cost: a) the fair value is calculated at the grant
} 
However, excess compensation is not relevant. This may imply that it is the very amount of CEO remuneration, irrespective of firm-specific circumstances, to generate shareholder dissent. Consistently, dissent is positively correlated also to a dummy capturing whether a CEO turnover took place in 2011 (a proxy for the remittance of severance payments to leaving CEOs); the relation is, however, weak.

\section{Insert Table 5 about here.}

Further information may be drawn from the last model in Table 5, where CEO remuneration is defined in terms of quartiles, as common in previous literature (Cai \& Walkling 2011; Thomas, Palmiter \& Cotter 2012; Ertimur, Ferri \& Oesch 2013). Consistent with our expectations, dissent in Q4 (the top remuneration quartile) is much higher than in the rest of our sample (as can be inferred from the fact that the coefficients for the first three quartile dummies are negative and almost always statistically significant). We interpret this evidence as consistent with Hypothesis 2: dissent is positively correlated with CEO pay, particularly when remuneration is very high (in the top quartile) and/or when it includes a substantial amount of equity-based remuneration, irrespective of the specific circumstances of the individual firm. We also see the positive relation between dissent and equity-based pay as consistent with investors considering stock-options and -grants more prone to managerial rent extraction.

Table 6 shows the results when dissent is regressed on ownership structure variables. As predicted, shareholder dissent is negatively correlated with ownership concentration, defined alternatively in terms of the cash-flow and the voting rights of the ultimate shareholder. This effect is quite strong: the value of the coefficients is very high, and their p-value is close to zero. One might be tempted to attribute this result to high ownership concentration effectively preventing engagement by minority shareholders: the higher the stake held by control shareholders, the less water remains in the pool where active investors may swim. While this viewpoint may have some merit, we underline that the average (median) voting rights are only 51\% (55\%), leaving considerable room for voting dissent by active shareholders (remind that the average dissent is just around $5 \%$ of total votes cast). Consequently, we tend to attribute the negative relation between ownership concentration and dissent to shareholders holding a higher stake performing better their monitoring role over management, thereby generating lower agency costs and, ultimately, lower dissent. Separation between ownership and control, measured by the CFR-VR wedge is utterly irrelevant.

\section{Insert Table 6 about here.}

\footnotetext{
date, and will not change subsequently, even though the value of the stock instruments may increase or decrease remarkably over time; b) the fair value is typically expensed along the vesting period, implying that, often, only a fraction of the cost is reported in the RR of a single year. Consequently, the fair value included in our regressions may not capture all the features of equity-based pay potentially relevant for shareholder voting decisions.
} 
We interpret this evidence as consistent with the first part of Hypothesis 3: dissent is negatively correlated with the equity stake held by the controlling shareholder. Our evidence is, however, inconsistent with the second part of this hypothesis, since dissent is not correlated with separation of ownership from control. We attribute the latter result to the low value of the wedge in Italian companies. The recourse to control-enhancing mechanisms (dual class shares and pyramids) has decreased remarkably over the last 20 years (Bianchi \& Bianco 2006). This makes the conventional picture of Italy as a country of extreme separation fundamentally outdated (Belcredi \& Enriques 2013).

The last regression in Table 6 considers the identity of the ultimate shareholder (through a set of dummies calculated against widely held companies). Consistent with the interpretation previously outlined, dissent is much lower where a controlling shareholder is present; the effect is somewhat stronger for family firms and for the subsidiaries of widely-held listed companies. It may be interesting to underline that the negative coefficient is lower, in absolute terms, for companies controlled by coalitions of shareholders, where free rider problems associated with monitoring costs are arguably more relevant.

Table 7 reports the results of regressions performed on proxies for investor activism (presence of minority directors and institutional investors' turnout at the shareholder meeting). As predicted, shareholder dissent is positively correlated with activism. The effect is particularly strong (and statistically significant, with a p-value close to zero) in the case of minority directors, especially when activism is proxied through minority directors sitting in the remuneration committee. Directors drawn from Assogestioni slates have, apparently, no additional impact (both at the board and at the committee level). However, this might be due to the low number of companies where mutual funds have actually appointed their candidates (Assogestioni slates are submitted almost exclusively in blue chips: Belcredi, Bozzi \& Di Noia 2013). Incidentally, it may be useful to remark that, once activism is included in the picture, the coefficient for total assets is no longer statistically significant. This effect is hardly surprising, given the positive relation between activism and firm size (see, once again, Table 2).

\section{Insert Table 7 about here.}

The broad picture is substantially unchanged when institutional investors' turnout is considered, instead of minority directors. Dissent is positively related to the presence of institutional investors (measured alternatively as a binary variable, taking value one if at least one investor of the category was present at the shareholders' meeting, or as the \% votes - summing up both positive and negative votes - cast by all investors in that category). The relation is statistically significant ( $\mathrm{p}$ value just below 10\%) for the percentage of votes cast by foreign funds, and is particularly strong for the Italian mutual funds dummy ( $p$-value close to zero). The turnout of domestic and foreign funds affects dissent in different ways: when Italian mutual funds show up at the shareholders' meeting (usually in large companies), the average dissent is higher; however, the percentage of votes they cast is irrelevant, indicating that either the whole category or, at least, the institutions actually voting "against" the remuneration policy command a negligible percentage of votes. On the 
contrary, the mere presence of foreign institutions at the shareholders' meeting has apparently no impact on the voting outcome; however, the percentage of votes they cast affects dissent positively. Actually, foreign funds are often present at shareholders' meetings and they do vote on the remuneration policy. When they decide to vote "against" the policy, their impact on the voting outcome is non-negligible, since they command a percentage of votes much higher than dissenting domestic funds. We interpret our results as broadly consistent with both parts of Hypothesis 4: dissent is positively correlated with investor activism.

Additional insights may be drawn from Table 8, reporting the results for our complete model, where independent variables relevant for each hypothesis are considered together. Our previous results are substantially confirmed: both the sign and statistical significance of the coefficients are generally unchanged, and the R2 is substantially higher (between 23 and 31\%). There are, however, some notable exceptions. In particular, while the effect of low disclosure remains strong, CEO compensation is no longer relevant: disclosure seems a stronger driver of dissent than CEO pay. In a sense, this result could be seen as expected: after all, shareholders vote on the first section of the Remuneration Report (the remuneration policy), and not on the second section, reporting the compensation actually paid to directors ${ }^{11}$. Ownership structure and investor activism are always quite relevant. The presence of Italian mutual funds at the shareholders' meeting also confirms to be a stronger driver of dissent than the turnout (in \% terms) of foreign funds.

\section{Insert Table 8 about here.}

Amongst control variables, firm size is no longer statistically significant. This is hardly surprising after the previous discussion, since the models in Table 8 include CEO compensation and proxies for investor activism, which are clearly correlated with firm size. Interestingly, the financial/non-financial dummy is still negative but no longer relevant, indicating that regulatory differences, in general, are not a particularly strong driver of shareholder dissent.

\section{2. $\quad$ Results for the high-dissent voting model}

Further insights can be gained through the analysis of the results of our alternative voting model, based on a logistic specification, trying to capture the determinants of "high" (i.e. above average) shareholder dissent. Basically, through this analysis we try to identify whether cases of high dissent are correlated with factors which may not perfectly coincide with those identified in the previous paragraph.

The broad picture remains unchanged: high dissent is more likely in larger firms and in the non-financial sector (where the shareholder vote is non-binding), where CEO compensation is higher, where ownership is more concentrated and, finally, where activism (as proxied by the

\footnotetext{
${ }^{11}$ This point will, however, need to be further qualified in the following paragraph.
} 
presence of minority directors and/or institutional investors' turnout) is stronger. However, some remarkable differences are present and deserve careful analysis.

Table 9 presents the main results of our analysis when the high-dissent dummy is regressed against disclosure and CEO remuneration variables ${ }^{12}$. First, the coefficient for the disclosure dummy (capturing the quality of information disclosed on variable pay) is still positive but is no longer statistically significant. This seems to indicate that, while low quality disclosure is likely to attract "some" negative votes, cases of high dissent are likely driven by other factors, possibly investing the structure and amount of CEO remuneration.

\section{Insert Table 9 about here.}

Actually, this seems to be the case in Italian firms: the models 2-8 in Table 9 show a clear picture, which is also consistent with the findings of the literature for Anglo-Saxon countries. High dissent is positively (and strongly) correlated with CEO remuneration in almost all the specifications proposed ( $p$-values are close to zero, in particular, for total remuneration and for fixed pay, usually accounting for a substantial part of the total in Italy: Assonime-Emittenti Titoli 2013). It may be usefully underlined that, contrary to what happened in the first set of regressions, also excess compensation is here statistically significant ( $\mathrm{p}$-value around 6\%). Finally, a particular attention deserves the last regression in Table 9, reporting results for remuneration quartiles: the coefficients are much stronger than in the previous analysis. Furthermore, the relation appears now much clearer, with the probability of high shareholder dissent monotonically increasing (and the pvalues monotonically decreasing) with remuneration quartiles.

Table 10 reports regressions conducted on proxies for investor activism. While the broad picture is substantially in line with the previous analysis (the signs of the coefficients are unchanged and the R2 of the regressions is even substantially higher), some differences emerge with respect to their impact of our activism proxies (and their statistical significance).

\section{Insert Table 10 about here.}

The probability of high shareholder dissent is only weakly correlated with the presence of minority directors on the board. Only the coefficient for their presence in the Remuneration committee reaches a p-value below 10\%. On the opposite, the coefficients for the institutional investors' turnout are much stronger, indicating that a high shareholder dissent is much more likely where Italian funds are present at the general meeting ( $p$-value close to zero) and where foreign funds command a higher $\%$ of votes (p-value around $2 \%$ )

\footnotetext{
${ }^{12}$ We omit reporting results simply confirming our OLS analysis. This is the case, for example, of regressions conducted on firm ownership structure.
} 
Finally, Table 11 reports the results for our complete logistic model, where independent variables relevant for each Hypothesis are considered together. Once again, our previous results are substantially confirmed: both the sign and statistical significance of the coefficients are generally unchanged, and the R2 is substantially higher (between 20 and 29\%). However, contrary to what happened in our former, OLS specification, high dissent seems to be strongly correlated to CEO total compensation, while the low disclosure dummy is no longer relevant: therefore, CEO pay seems a stronger driver of high dissent than disclosure. Taken together, our results suggest that while low quality disclosure is likely to attract some negative votes, cases of high dissent are likely driven by investors' concerns about current CEO remuneration (e.g. they might consider his/her pay package as excessive and/or poorly structured).

\section{Insert Table 11 about here.}

High dissent is still positively related to our proxies for activism, However, contrary to what happened in our OLS analysis, it is associated with a higher turnout (in \% terms) of foreign funds, while the presence of Italian mutual funds at the shareholders' meeting is not statistically significant. Consequently, high dissent seems relatively more likely where the turnout of foreign funds is higher (as is typical in larger firms) and where they have concerns with the current remuneration package. Interestingly, the financial/non-financial dummy is here statistically significant, indicating that high dissent is less likely in financial firms. This might be associated, in turn, with higher investor self-restrain, due to the binding nature of the vote, or with less controversial pay packages, due to the specific regulation of remuneration in financial firms.

\section{Conclusions}

This paper is the first attempt to investigate shareholders' dissent on remuneration policies in a country where listed companies' ownership structure is highly concentrated. At the end of 2010 Italy introduced a new regulation on say-on-pay requiring listed companies to submit the remuneration policy to a mandatory non-binding vote of all shareholders. We provide a first evidence on whether SOP has been taken advantage of by shareholders to express their dissenting opinion, and investigate the drivers of shareholders' dissent.

We come up with some results which may be of interest for both scholars and regulators. Firstly, we find that dissent is higher in widely held firms and negatively correlated with the equity stake held by the largest shareholder. We interpret this result as a consequence of reduced agency costs in controlled firms, where the high stake held by the controlling shareholder is supposed to decrease his incentives to deviate from value maximization. Interestingly, despite the negative correlation between ownership concentration and negative SOP votes, the level of dissent recorded in Italy is comparable with what found in other countries, where ownership is disperse (i.e. the UK and the US). 
Secondly, we find that dissent is positively correlated with CEO remuneration; this mainstream result from the existing UK and US literature is confirmed under concentrated ownership, and it is particularly robust when tail cases of dissent are considered. While high dissent is mainly explained by the level of CEO compensation, dissent in general is higher when the remuneration policy is unclear or disclosure is vague, especially on the variable components. This original result may suggest that in contexts with limited tradition on remuneration disclosure a preliminary condition for market scrutiny to work is the existence and readability of information in the first place.

Thirdly, as expected, institutional investors' engagement affects voting dissent. We find that both the turnout of institutional investors at the AGM and the presence of at least one minority director in the board (and in the Remuneration Committee) increase the level of dissent. However, while dissent is mainly due to Italian institutional investors, when we turn to the analysis of the drivers of high dissent, the share held by foreign institutions has a stronger explanatory power. This result might simply be explained by foreign investors, holding larger average stakes, being more reluctant to actively voice their discord, i.e. becoming active only in tail cases. This outcome also adds new evidence to the empirical literature investigating the monitoring role exerted by institutional investors, suggesting that domestic investors bear most of the costs of activism and perform a useful role in aggregating dissent.

Finally, the non-binding nature of the SOP vote does not reduce its effectiveness. Actually, evidence from the financial sector demonstrates that, where the SOP vote is binding, shareholders tend to dissent less than in the case of a standard listed company. Taken together, these results can be interpreted as an indication that non-binding SOP vote does not necessarily impact negatively on the shareholders' incentives to voice their disagreement. On the contrary, they may exert selfrestraint where the vote is binding and feel freer to voice their disappointment where it is nonbinding. 


\section{References}

Alissa, W. M. 2009. Boards' response to shareholders' dissatisfaction: The case of shareholders' say on pay in the UK. Working Paper, available at www.ssrn.com.

Armstrong, C. S., Gow, I. D. \& Larcker, D. F. 2013. The efficacy of shareholder voting: Evidence from equity compensation plans. Journal of Accounting Research, 51: 909-950.

Arslan, O. \& Karan, M. B. 2006. Ownership and control structure as determinants of corporate debt maturity: a panel study of an emerging market. Corporate Governance: An International Review, 14: 312-324.

Assonime-Emittenti Titoli 2013. Corporate governance in Italy. Compliance with the CG Code and directors' remuneration. Note \& Studi No. 5/2013, available at www.assonime.it.

Balsam, S. \& Yin, J. 2012. The impact of say-on-pay on executive compensation. Working Paper, available at www.ssrn.com.

Barca, F. \& Becht, M. (eds.), The Control of Corporate Europe, Oxford, Oxford University Press, 2001.

Barontini, R. \& Bozzi, S. 2011. Board compensation and ownership structure: empirical evidence for Italian listed companies. Journal of Management and Governance, 15: 59-89.

Barontini, R., Bozzi, S., Ferrarini, G. \& Ungureanu, M. C. 2013. Directors' remuneration before and after the crisis: measuring the impact of reforms in Europe, in Belcredi, M. \& Ferrarini, G. Boards and shareholders in European listed companies. Facts, contexts and reform proposals. Cambridge University Press, 251-315.

Barontini, R. \& Caprio, L. 2006. The effect of family control on firm value and performance. Evidence from continental Europe. European Financial Management, 12: 689-723.

Barucci, E. \& Falini, J. 2005. Determinants of corporate governance in the Italian financial market, Economic Notes, 34: 371-405.

Bebchuk, L. A., Friedman, A. T. \& Friedman, W. J. 2007. Empowering shareholders on executive compensation: hearing on H.R. 1257 before the House Committee on Financial Services, 110th Cong. 68, available at www.gpo.gov.

Bebchuk, L. A., Kraakman, R. \& Triantis, G. 2000. Stock pyramids, cross-ownership and dual-class equity. The mechanisms and agency costs of separating ownership from control, in Morck, R. (ed.) Concentrated corporate ownership. University of Chicago Press, 445-460.

Belcredi, M., Bozzi, S. \& Di Noia, C. 2013. Board elections and shareholder activism: The Italian experiment in Belcredi, M. \& Ferrarini, G. Boards and shareholders in European listed companies. Facts, contexts and reform proposals. Cambridge University Press, 369-425.

Belcredi, M. \& Enriques, L. 2013. Institutional investor activism in a context of concentrated ownership and high private benefits of control: the case of Italy. ECGI Law Working Paper no. 
Bianchi, M., Bianco, M. \& Enriques, L. 2001. Pyramidal Groups and the Separation Between Ownership and Control in Italy. In Barca, F. and Becht, M. (eds.), The Control of Corporate Europe, Oxford University Press, Oxford.

Bianchi, M. \& Enriques, L. 2005. Corporate Governance in Italy after the 1998 Reform: What role for Institutional Investors? Corporate Ownership and Control, 2: 11-31.

Bianchi, M. \& Bianco M. 2006. Italian corporate governance in the last 15 years. From pyramids to coalitions?, ECGI Finance Working Paper no. 144/2006.

Bianchi, M., Ciavarella, A., Novembre, V. \& Signoretti, R. 2010. Comply or Explain? Investor Protection through Corporate Governance Codes. ECGI Finance Working Paper 278/2010.

Bianco, M. 2001. Italy. In Gugler, K. (ed.), Corporate Governance and Economic Performance, Oxford University Press.

Brav, A., Jiang, W., Partnoy F. \& Thomas, R. 2008. Hedge fund activism, corporate governance, and firm performance. Journal of Finance, 63: 1729-1765.

Cai, J. \& Walkling, R. E. 2011. Say on pay: Does it create value?. Journal of Financial and Quantitative Analysis, 46: 299-339.

Carter, M. E. \& Zamora, V. 2009. Shareholder remuneration votes and CEO compensation design. Boston University Working Paper, available at www.ssrn.com.

Chung, K. H. \& Zhang, H. 2011. Corporate governance and institutional ownership. Journal of Financial and Quantitative Analysis, 46: 247-273.

Claessens, S. \& Yurtoglu, B. (2013). Corporate Governance In Emerging Markets: A Survey. Emerging markets review, 15:1-33.

Conyon, M. \& Sadler, G. 2010. Shareholder voting and directors' remuneration report legislation: Say on pay in the UK. Corporate Governance: An International Review, 18: 296-312.

CONSOB, 2013. Report on Corporate Governance of Italian listed companies, available at www.CONSOB.it.

Core, J. E., Holthausen, R. W., \& Larcker, D. F. 1999. Corporate governance, chief executive officer compensation, and firm performance. Journal of financial economics, 51: 371-406.

Croci, E. 2007. Corporate Raiders, Performance and Governance in Europe. European Financial Management, 13: 949-978.

Croci, E., Gonenc, H. \& Ozkan, N. 2010. CEO compensation, family control and institutional investors in continental Europe, available at www.ssrn.com.

Da Silveira, A. M., Leal, R. P. C., Carvalhal-da-Silva, A. L. \& Barros, L. A. B. C. 2008. Evolution and determinants of firm-level corporate governance quality in Brazil. Oxford Business and Economics Conference 2008 Working Paper, available at www.ssrn.com. 
Del Guercio, D. 1996. The distorting effect of the prudent-man laws on institutional equity investment, Journal of Financial Economics, 40: 31-62.

Del Guercio, D., Seery, L. \& Woidtke, T. 2008. Do Boards Pay Attention when Institutional Investor Activists 'Just Vote No'? Journal of Financial Economics, 90: 84-103.

European Commission 2012. Action Plan: European company law and corporate governance - a modern legal framework for more engaged shareholders and sustainable, available at http://eurlex.europa.eu.

Ertimur, Y, Ferri, F. \& Muslu, V. 2011. Shareholder activism and CEO pay. Review of Financial Studies, 24: 535-592.

Ertimur, Y., Ferri, F. \& Oesch, D. 2013. Shareholder votes and proxy advisors: Evidence from say on pay. Journal of Accounting Research, 51: 951-996.

Ertimur, Y, Ferri, F. \& Stubben, S. R. 2010. Board of directors' responsiveness to shareholders: Evidence from shareholder proposals. Journal of Corporate Finance, 16: 53-72.

Eulerich, M., Rapp, M. S. \& Wolf, M. 2012. Ausgewählte Aspekte der Vorstandsvergütung: Sayon-Pay-Abstimmungen im Rahmen der Hauptversammlung - Ergebnisse einer empirischen Analyse der HV-Saison 2010. HHL Research papers in Corporate Governance, Leipzig School of Management, No.7/2012, available at www.ssrn.com.

Faccio, M. \& Lang, L. H. P. 2002. The ultimate ownership of Western European corporations. Journal of Financial Economics, 65: 365-395.

Fama, E. \& Jensen, M. C. 1983. Separation of ownership and control. Journal of Law and Economics, 26: 301-325.

Ferri, F. \& Maber, D. A. 2013. Say on pay votes and CEO compensation: Evidence from the UK. Review of Finance, 17: 527-563.

Ferri, F. \& Sandino, T. 2009. The Impact of Shareholder Activism on Financial Reporting and Compensation: The Case of Employee Stock Options Expensing. The Accounting Review, 84: 433466.

Gillan, S. L. \& Starks, L. T. 1998. A survey of shareholder activism: Motivation and empirical evidence. Contemporary Finance Digest, 2: 10-34.

Gillan, S. L. \& Starks, L. T. 2007. The evolution of shareholder activism in the United States, Journal of Applied Corporate Finance, 19: 55-73.

Goex, R. F., Imhof, F. \& Kunz, A. H. 2012. Say on pay design and its repercussions on CEO incentives, compensation and firm profit. Working Paper, available at www.ssrn.com.

Gordon, J. N. 2009. "Say on pay": cautionary notes on the U.K. experience and the case for shareholder opt-in. Harvard Journal on Legislation, 46: 323-341. 
ISS (International Shareholder Services) 2011. 2011 U.S. Postseason Report, available at www.iss.com.

ISS (International Shareholder Services) 2013. 2012 Proxy Season Review. World Markets, available at www.iss.com.

Jensen, M. C. \& Meckling, W. H. 1976. Theory of the firm. Managerial behavior, agency costs and ownership structure. Journal of Financial Economics, 3: 305-360.

Jensen, M. C. \& Murphy, K. J. 1990. CEO Incentives - It's not how Much you Pay, but How. Harvard Business Review, May-June, 138-53.

Johnson, M. F., Porter, S. \& Shackell, M. B. 1997. Stakeholder pressure and the structure of executive compensation. Working Paper, available at www.ssrn.com.

Johnson, M. F. \& Shackell, M. B. 1997. Shareholder proposals on executive compensation. Working Paper, available at www.ssrn.com.

Kaplan, S. 2007. Empowering shareholders on executive compensation: hearing on H.R. 1257 before the House Committee on Financial Services, 110th Cong. 126, available at http://www.gpo.gov.

Kato, T. \& Long, C. 2006. CEO turnover, firm performance, and enterprise reform in China: Evidence from micro data. Journal of Comparative Economics, 34: 796-817.

Kimbro, M. B. \& Xu, D. 2013. Shareholders have a say on executive compensation: Evidence from say-on-pay in the United States. Working Paper, available at www.ssrn.com.

Klein, A. \& Zur, E. 2009. Entrepreneurial Shareholder Activism: Hedge Funds and Other Private Investors. Journal of Finance, 64: 187-229.

La Porta, R., Lopez-de-Silanes, F. \& Shleifer, A. 1999. Corporate ownership around the world, Journal of Finance, 54: 471-517.

Levit, D. \& Malenko, N. 2011. Nonbinding voting for shareholder proposals. Journal of Finance, 66: 1579-1614.

Morgan, A., Poulsen, A., \& Wolf, J. 2006. The evolution of shareholder voting for executive compensation schemes. Journal of Corporate Finance, 12: 715-737.

Nenova, T. 2003. The value of corporate voting rights and control: A cross-country analysis, Journal of Financial Economics, 68: 325-351.

Parrino, R., Sias, R.W. \& Starks, L. T. 2003. Voting with their feet: Institutional ownership changes around forced CEO turnover. Journal of Financial Economics, 68: 3-46.

Renneboog, L. \& Szilagyi, P. 2013. Shareholder engagement at European general meetings, in Belcredi, M. \& Ferrarini, G. Boards and shareholders in European listed companies. Facts, contexts and reform proposals. Cambridge University Press, 251-315. 
Rosen, S. 1982. Authority, control, and the distribution of earnings. Bell Journal of Economics, 13: 311-323.

Smith, C. W. \& Watts, R. L. 1992. The investment opportunity set and corporate financing, dividend, and financing policies. Journal of Financial Economics, 32: 262-292.

Thomas, R. S., Palmiter, A. R. \& Cotter, J. F. 2012. Dodd-Frank's say-on-pay. Will it lead to a greater role for shareholders in corporate governance? Cornell Law Review, 97: 1213-1266.

Wagner, A. F. \& Wenk, C. 2013. Agency versus hold-up. On the impact of binding say-on-pay on shareholder value. Working Paper, available at www.ssrn.com.

Yermack, D. 2010. Shareholder voting and corporate governance. Annual Review of Financial Economics, 2: 103-125. 


\section{Appendix: Variable definitions}

LNTotAsset: Natural logarithm of Total Assets

\section{ROA: Accounting returns (EBITDA ${ }_{\mathrm{t}} /$ Total Assets $\left._{\mathrm{t}}\right)$}

$M / B$ (Market to Book ratio): market value of the ordinary (common) equity divided by book value of the ordinary (common) equity

QRatio: Market value of Equity and Total Debt divided by book value of Equity and Total Debt

RET3Y (Stock returns over the last 3 Years): average dividend-adjusted stock returns over the last 3 years prior to the shareholders' meeting year.

SQM_RET (Standard deviation of stock returns): the standard deviations of stock returns over the last year prior to the shareholders' meeting year.

Fin/Nonfin: dummy variable that takes value 1 for financial companies and 0 otherwise.

Board_Size: Number of directors in a Board

CEOFixedPay: the amount of salary and benefits paid to the CEO

CEOVarCash: the amount of variable cash and bonus compensation paid to the CEO

CEOEquity: the annualized fair value of stock and options granted to the CEO

CEOTotComp: the sum of cash (Fixed + Variable) and equity-based CEO compensation

CEOExcessComp: the difference between actual and "predicted" CEO Total compensation. Predicted Total compensation is obtained by regressing the log of CEO Total Compensation pay on proxies for its "economic" determinants, as specified by previous research in this area (Rosen 1982; Smith \& Watts 1992; Core, Holthausen \& Larcker 1999): firm size, risk, contemporaneous and lagged performance, and investment opportunities.

DumQuartTotComp1, 2, 3, 4: dummy variables for quartiles of CEO Total compensation. DumQuartTotComp4 is the highest quartile and the reference point for the regression

Cash Flow Rights: the cash-flow rights held by the ultimate shareholder (US) after taking into account the whole chain of control (if US owns $50 \%$ of direct cash-flows of B and B owns $40 \%$ of direct cash-flows of C, then US owns ultimately $50 \% * 40 \%=20 \%$ of cash-flows of C)

Voting_Rights: the voting rights held by the ultimate shareholder in the weakest link along the control chain. $10 \%$ is the cutoff point for the existence of a control chain: a listed company that has no shareholder above $10 \%$ is considered widely held.

Wedge (Degree of separation of ownership from control): the difference between Voting and Cashflow rights.

Family (Family ownership): the ultimate shareholder is an individual or a group of individuals belonging to the same family 
State (State ownership): Dummy variable assuming value equal to one if the ultimate shareholder is the State or another public entity

Coalitions (Companies controlled by coalitions): Dummy variable assuming value equal to one if the ultimate shareholder is a coalition of various subjects

Controlled_WH (Companies controlled by widely held firms): Dummy variable assuming value equal to one if the ultimate shareholder is a widely-held listed company

PrivateEquity: (Companies controlled by private equity funds): Dummy variable assuming value equal to one if the ultimate shareholder is a private equity fund

Dummy CEO Turnover: dummy variable that takes value 1 if the CEO has changed in $\mathrm{t}-1$, and 0 otherwise

Disclosure Rem. Composition (Fixed/Variable): dummy variable that takes value 1 if the company discloses the proportion of fixed and variable compensation in the Remuneration Report (RR), and 0 otherwise

Cap in Variable Compensation: dummy variable that takes value 1 if the company discloses the existence of a cap on directors' variable compensation in the RR, and 0 otherwise

Disclosure Performance Objectives: dummy variable that takes value 1 if the company describes the objectives of directors' performance-based pay in the RR, and 0 otherwise

Disclosure index: an index (ranging from 1 to 6) of the quality of RR disclosure. It is the sum of six dummy variables, based on the disclosure of items potentially relevant for investors' decisions: 1) Disclosure Rem. Composition (Fixed/Variable); 2) Cap in Variable Compensation; 3) Disclosure Performance Objectives; 4) A dummy based on the disclosure of multiple objectives for directors' variable compensation; 5) A dummy based on the disclosure of variable compensation deferral and, finally 6) A dummy based on the disclosure of a cap on directors' severance pay.

Dummy Low Disclosure: dummy variable that takes value 1 when the disclosure is low $(<4)$ and 0 otherwise

Chairman-CEO: dummy variable that takes value 1 if the Chairman is also the CEO of the company and 0 otherwise

Min. Directors in Board: dummy variable that takes value 1 if at least one minority director sits on the Board and 0 otherwise

Assogestioni directors in Board: dummy variable that takes value 1 if at least one minority director drawn by an Assogestioni slate sits on the Board and 0 otherwise

Min. Directors in Rem. Com.: dummy variable that takes value 1 if at least one minority director sits in the Remuneration Committee and 0 otherwise

Assogestioni directors in Rem. Com.: dummy variable that takes value 1 if at least one minority director drawn by an Assogestioni slate sits in the Remuneration Committee and 0 otherwise 
Presence of Foreign Funds (\%): percentage of ordinary shares held by foreign asset managers over total shares voting on SOP

Presence of Italian Insurance and Banks (\%): Percentage of ordinary shares held by Italian banks and Insurance companies over total shares voting on SOP

Presence of Italian Funds (\%): percentage of ordinary shares held by Italian asset managers over total shares voting on SOP

Dummy Foreign Funds: dummy variable that takes value 1 if at least one foreign asset manager votes on SOP

Dummy Italian Insurance and Banks: dummy variable that takes value 1 if at least one Italian bank or Insurance companies votes on SOP

Dummy Italian Funds: dummy variable that takes value 1 if at least one Italian asset manager votes on SOP

Lagged variables (in t-1) are identified as (_tm1). 
Tables

TABLE 1

Panel A: Descriptive statistics

\begin{tabular}{|c|c|c|c|c|c|c|}
\hline Variable & $n$ & Mean & S.D. & I Quart. & Median & III Quart. \\
\hline & & \multicolumn{3}{|c|}{ Firm Characteristics } & & \\
\hline LNTotAssets & 226 & 5.87 & 0.94 & 5.2 & 5.66 & 6.47 \\
\hline$M / B$ & 226 & 0.97 & 2.99 & 0.43 & 0.76 & 1.4 \\
\hline ROA (\%) & 226 & 4.05 & 0.13 & 0.63 & 5.82 & 0.1 \\
\hline QRatio & 226 & 1.13 & 0.98 & 0.76 & 0.96 & 1.26 \\
\hline RET3Y (\%) & 222 & 12.12 & 0.08 & 6.79 & 10.6 & 15.59 \\
\hline \multirow[t]{2}{*}{$S Q M \_R E T$} & 223 & 1.10 & 0.80 & 0.59 & 0.91 & 1.28 \\
\hline & & \multicolumn{3}{|c|}{ CEO Compensation } & & \\
\hline CEOFixedPay (€.000) & 225 & 776 & 761 & 305 & 514 & 1019 \\
\hline CEOVarCash (€.000) & 225 & 410 & 1804 & 0 & 0 & 315 \\
\hline CEOEquity (€.000) & 225 & 172 & 983 & 0 & 0 & 0 \\
\hline \multirow[t]{2}{*}{ CEOTotComp (€.000) } & 225 & 1358 & 2533 & 329 & 671 & 1421 \\
\hline & & \multicolumn{3}{|c|}{ Ownership concentration } & & \\
\hline CF_Rights (\%) & 226 & 48.24 & 0.20 & 31.49 & 52.29 & 63.51 \\
\hline \multirow[t]{2}{*}{ Voting_Rights (\%) } & 226 & 51.46 & 0.18 & 37.23 & 54.92 & 64.69 \\
\hline & & \multicolumn{3}{|c|}{ CEO and Board Characteristics } & & \\
\hline CEO_Age & 222 & 55.96 & 9.61 & 49 & 55 & 62 \\
\hline \multirow[t]{2}{*}{ Board_Size } & 226 & 10.07 & 3.81 & 7 & 9 & 12 \\
\hline & & \multicolumn{3}{|c|}{ Institutional Investors } & & \\
\hline \multirow[t]{2}{*}{ Presence of Institutional Investors (\%) } & 226 & 5.15 & 0.09 & 0.00 & 0.97 & 7.35 \\
\hline & & & Dissent & & & \\
\hline Dissent (\%) & 226 & 5.13 & 0.11 & 0.00 & 0.14 & 3.76 \\
\hline
\end{tabular}




\begin{tabular}{|l|c|c|c|}
\hline \multicolumn{3}{|c|}{ TABLE 1 } \\
\hline \multicolumn{2}{|c|}{ Panel B: Descriptive statistics for dummy variables } \\
\hline \multicolumn{1}{|c|}{ Variables } & Sample & N. Firms & $\%$ \\
\hline Financial/Nonfinancial & 226 & 16 & $7 \%$ \\
\hline Chairman-CEO & 225 & 65 & $29 \%$ \\
\hline Minority directors in the Board & 226 & 90 & $40 \%$ \\
\hline Assogestioni directors in the Board & 226 & 13 & $6 \%$ \\
\hline Remuneration Committee & 226 & 198 & $88 \%$ \\
\hline Minority directors in Rem. Comm. & 198 & 47 & $24 \%$ \\
\hline Assogestioni directors in Rem. Comm. & 198 & 10 & $5 \%$ \\
\hline Variable pay provided for directors & 223 & 169 & $76 \%$ \\
\hline Disclosure of pay composition (fixed/variable) & 169 & 122 & $72 \%$ \\
\hline Disclosure of cap on variable pay & 169 & 141 & $83 \%$ \\
\hline
\end{tabular}




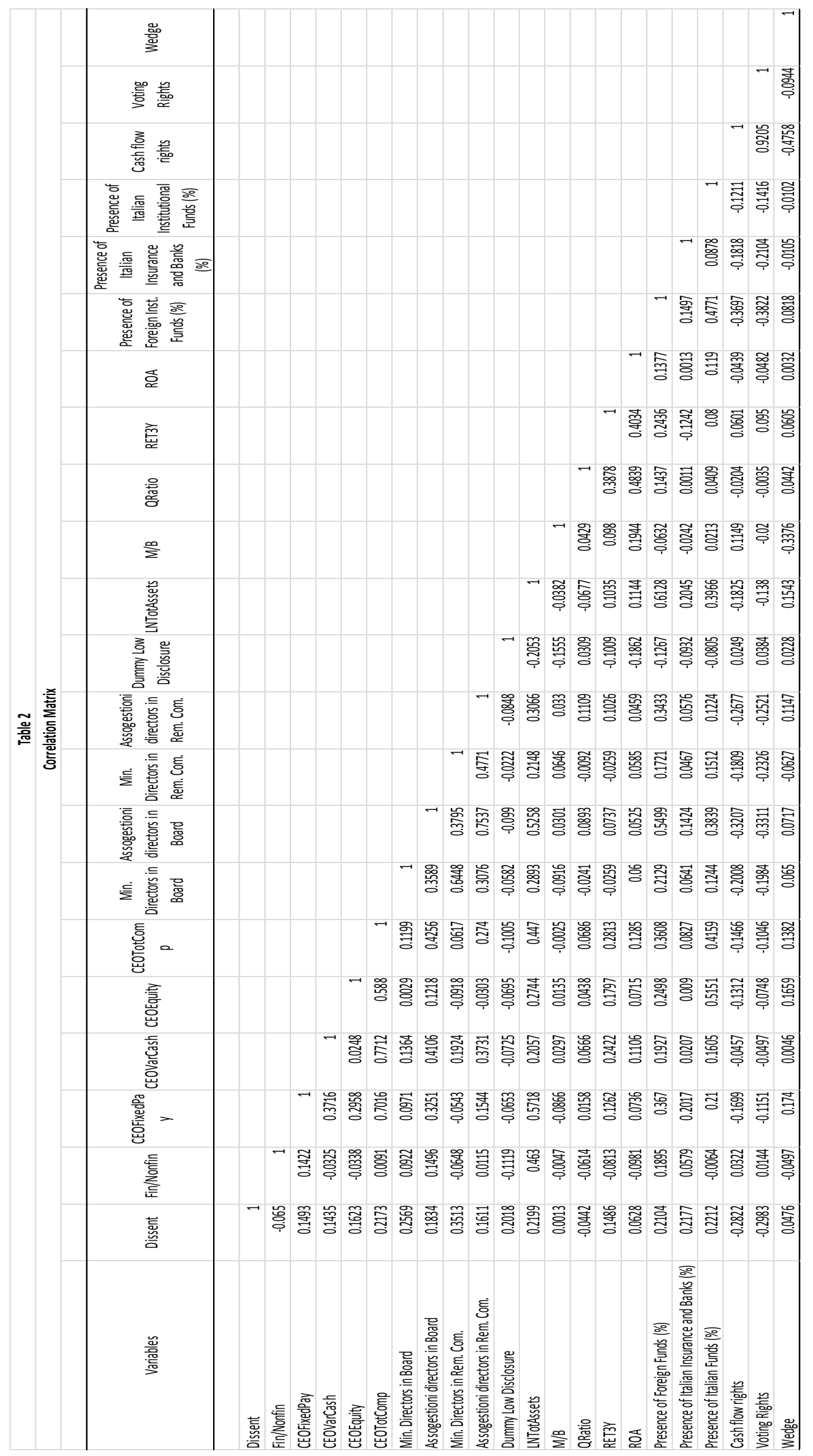




\section{TABLE 3}

Shareholder dissent on SOP and firm characteristics

\begin{tabular}{|c|c|c|c|c|}
\hline \multirow[t]{2}{*}{ LNTotAssets } & $0.0263 * * *$ & $0.0263 * * *$ & & \\
\hline & {$[0.0064]$} & {$[0.0062]$} & & \\
\hline \multirow[t]{2}{*}{$\mathrm{M} / \mathrm{B}$} & 0.0012 & 0.0019 & & \\
\hline & {$[0.6445]$} & {$[0.4580]$} & & \\
\hline \multirow[t]{2}{*}{ ROA } & -0.0972 & -0.0581 & & \\
\hline & {$[0.1409]$} & {$[0.3313]$} & & \\
\hline \multirow[t]{2}{*}{ QRatio } & 0 & & & \\
\hline & {$[0.9994]$} & & & \\
\hline \multirow[t]{2}{*}{ LNTotAssets_tm1 } & & & $0.0290 * * *$ & $0.0286 * * *$ \\
\hline & & & {$[0.0021]$} & {$[0.0026]$} \\
\hline \multirow[t]{2}{*}{ M/B_tm1 } & & & -0.0012 & -0.0006 \\
\hline & & & {$[0.4747]$} & {$[0.7090]$} \\
\hline \multirow[t]{2}{*}{ ROA_tm1 } & & & -0.0815 & -0.0372 \\
\hline & & & {$[0.2808]$} & {$[0.6014]$} \\
\hline \multirow[t]{2}{*}{ QRatio_tm1 } & & & 0.0004 & \\
\hline & & & {$[0.7044]$} & \\
\hline \multirow[t]{2}{*}{ Fin/Nonfin } & $-0.0685^{* *}$ & $-0.0703^{* *}$ & $-0.0736 * *$ & $-0.0734 * *$ \\
\hline & {$[0.0248]$} & {$[0.0225]$} & [0.0139] & {$[0.0156]$} \\
\hline \multirow[t]{2}{*}{ RET3Y } & 0.1307 & & 0.1173 & \\
\hline & {$[0.2091]$} & & {$[0.2344]$} & \\
\hline \multirow[t]{2}{*}{ SQM_RET } & -0.0009 & 0.005 & -0.0026 & 0.0023 \\
\hline & [0.9293] & {$[0.5975]$} & {$[0.7907]$} & {$[0.8095]$} \\
\hline \multirow[t]{2}{*}{ Constant } & $-0.1123^{*}$ & $-0.1035^{*}$ & $-0.1219 * *$ & $-0.1127 * *$ \\
\hline & {$[0.0511]$} & [0.0649] & {$[0.0261]$} & {$[0.0421]$} \\
\hline R-squared & 0.0507 & 0.0412 & 0.0615 & 0.0478 \\
\hline Observations & 222 & 223 & 221 & 222 \\
\hline
\end{tabular}

$*, * *, * * *$ indicate a $\mathrm{p}$-value of coefficients $<10 \%, 5 \%, 1 \%$, respectively 
TABLE 4

Shareholder dissent on SOP and quality of disclosure on remuneration

\begin{tabular}{|c|c|c|c|c|c|}
\hline & {$[0.0002]$} & [0.0009] & {$[0.0017]$} & {$[0.0016]$} & {$[0.0020]$} \\
\hline \multirow[t]{2}{*}{$M / B$} & 0.002 & 0.0009 & -0.0002 & 0.0008 & 0.0013 \\
\hline & {$[0.4500]$} & {$[0.8596]$} & [0.9685] & {$[0.8773]$} & {$[0.6317]$} \\
\hline \multirow[t]{2}{*}{ Fin/Nonfin } & $-0.0699 * *$ & $-0.0751 * *$ & $-0.0734 * *$ & $-0.0750 * *$ & $-0.0740 * *$ \\
\hline & {$[0.0378]$} & {$[0.0283]$} & {$[0.0318]$} & {$[0.0285]$} & {$[0.0330]$} \\
\hline \multirow[t]{2}{*}{ ROA } & 0.0313 & 0.02 & 0.0163 & 0.0162 & 0.0103 \\
\hline & {$[0.6282]$} & {$[0.7640]$} & [0.8066] & {$[0.8076]$} & {$[0.8765]$} \\
\hline \multirow[t]{2}{*}{ SQM_RET } & -0.0013 & 0.0005 & 0.0018 & 0.0004 & -0.0017 \\
\hline & {$[0.8965]$} & [0.9612] & {$[0.8561]$} & {$[0.9722]$} & {$[0.8684]$} \\
\hline \multirow[t]{2}{*}{ Dummy Low Disclosure } & $0.0852 * * *$ & & & & \\
\hline & [0.0011] & & & & \\
\hline \multirow[t]{2}{*}{ Disclosure Rem. Composition (Fixed/Variable) } & & -0.0154 & & & \\
\hline & & [0.4339] & & & \\
\hline \multirow[t]{2}{*}{ Cap in Variable Compensation } & & & 0.0224 & & \\
\hline & & & [0.3303] & & \\
\hline \multirow[t]{2}{*}{ Disclosure Performance Objectives } & & & & 0.0336 & \\
\hline & & & & {$[0.3784]$} & \\
\hline \multirow[t]{2}{*}{ Disclosure index } & & & & & -0.0048 \\
\hline & & & & & {$[0.4854]$} \\
\hline \multirow[t]{2}{*}{ Constant } & $-0.1786 * * *$ & $-0.1442^{* *}$ & $-0.1581 * *$ & $-0.1714^{* *}$ & $-0.1239 * *$ \\
\hline & {$[0.0043]$} & {$[0.0233]$} & {$[0.0154]$} & [0.0157] & {$[0.0472]$} \\
\hline R-squared & 0.1232 & 0.077 & 0.0789 & 0.0779 & 0.0667 \\
\hline Observations & 169 & 166 & 166 & 166 & 169 \\
\hline
\end{tabular}

$*, * *, * * *$ indicate a $\mathrm{p}$-value of coefficients $<10 \%, 5 \%, 1 \%$, respectively 
TABLE 5

Shareholder dissent on SOP and CEO compensation and turnover

\begin{tabular}{|c|c|c|c|c|c|c|c|c|}
\hline \multirow[t]{2}{*}{ LNTotAssets } & $0.0235^{* *}$ & & & & & & & \\
\hline & [0.0235] & & & & & & & \\
\hline \multirow[t]{2}{*}{$M / B$} & 0.002 & 0.0014 & 0.0016 & 0.0012 & 0.0012 & 0.0013 & 0.0012 & 0.0021 \\
\hline & [0.4437] & [0.5956] & [0.5402] & [0.6353] & {$[0.6365]$} & [0.6227] & {$[0.6476]$} & {$[0.4226]$} \\
\hline \multirow[t]{2}{*}{ Fin/Nonfin } & $-0.0700 * *$ & -0.0324 & -0.0391 & -0.03 & -0.0299 & -0.0296 & -0.0313 & $\begin{array}{l}3-0.0316 \\
\end{array}$ \\
\hline & [0.0255] & {$[0.2250]$} & [0.1515] & {$[0.2640]$} & {$[0.2644]$} & [0.2845] & {$[0.2443]$} & [0.2434] \\
\hline \multirow[t]{2}{*}{ ROA } & -0.0536 & -0.0269 & -0.0228 & -0.0166 & -0.0182 & -0.0169 & -0.0058 & $3 \quad-0.0122$ \\
\hline & [0.3735] & [0.6521] & [0.7019] & {$[0.7808]$} & {$[0.7582]$} & [0.7799] & {$[0.9215]$} & [0.8390] \\
\hline \multirow[t]{2}{*}{ CEOTotComp } & 0.0000 & $0.0000 * *$ & & & & & & \\
\hline & [0.3410] & [0.0433] & & & & & & \\
\hline \multirow[t]{2}{*}{ CEOFixedPay } & & & $0.0000^{*}$ & & & & & \\
\hline & & & [0.0948] & & & & & \\
\hline \multirow[t]{2}{*}{ CEOVarCash } & & & & 0.0000 & & & & \\
\hline & & & & {$[0.2725]$} & & & & \\
\hline \multirow[t]{2}{*}{ CEOEquity } & & & & & $0.0000^{*}$ & & & \\
\hline & & & & & [0.0589] & & & \\
\hline \multirow[t]{2}{*}{ CEOExcess Comp } & & & & & & -0.0025 & & \\
\hline & & & & & & {$[0.7646]$} & & \\
\hline \multicolumn{2}{|l|}{ Dummy Ceo turnover } & & & & & & 0.0381 & \\
\hline & & & & & & & [0.1652] & \\
\hline \multicolumn{2}{|l|}{ DumQuartTotComp3 } & & & & & & & $-0.0476 * *$ \\
\hline & & & & & & & & [0.0251] \\
\hline \multicolumn{2}{|l|}{ DumQuartTotComp2 } & & & & & & & -0.0179 \\
\hline & & & & & & & & [0.4038] \\
\hline \multicolumn{2}{|l|}{ DumQuartTotComp1 } & & & & & & & $-0.0448 * *$ \\
\hline & & & & & & & & [0.0432] \\
\hline \multirow[t]{2}{*}{ Constant } & -0.0841 & $0.0457 * * *$ & $0.0410 * * *$ & $0.0517^{* * *}$ & $0.0511 * * *$ & $0.0524 * * *$ & $0.0501 * * *$ & $0.0797 * * *$ \\
\hline & [0.1464] & {$[0.0000]$} & {$[0.0004]$} & {$[0.0000]$} & {$[0.0000]$} & {$[0.0000]$} & {$[0.0000]$} & {$[0.0000]$} \\
\hline R-squared & 0.0478 & 0.0252 & 0.0194 & 0.0123 & 0.0229 & 0.0067 & 0.0156 & $\quad 0.0368$ \\
\hline Observations & 225 & 225 & 225 & 225 & 225 & 218 & 225 & 225 \\
\hline
\end{tabular}

$*, * *, * * *$ indicate a $p$-value of coefficients $<10 \%, 5 \%, 1 \%$, respectively 


\begin{tabular}{|c|c|c|c|c|}
\hline \multicolumn{5}{|c|}{ TABLE 6} \\
\hline \multicolumn{5}{|c|}{ Shareholder dissent on SOP and ownership structure } \\
\hline \multirow[t]{2}{*}{ LNTotAssets } & $0.0190 * *$ & $0.0214 * *$ & $0.0272 * * *$ & $0.0212^{* *}$ \\
\hline & [0.0398] & {$[0.0178]$} & [0.0056] & {$[0.0279]$} \\
\hline \multirow[t]{2}{*}{$M / B$} & 0.0023 & 0.0009 & 0.0016 & 0.0018 \\
\hline & [0.3379] & {$[0.7051]$} & [0.5584] & {$[0.4718]$} \\
\hline \multirow[t]{2}{*}{ Fin/Nonfin } & $-0.0520 *$ & $-0.0578 * *$ & $-0.0725 * *$ & $-0.0741 * *$ \\
\hline & {$[0.0773]$} & [0.0452] & [0.0201] & [0.0188] \\
\hline \multirow[t]{2}{*}{ ROA } & -0.0443 & -0.0362 & -0.0571 & -0.0158 \\
\hline & [0.4363] & [0.5180] & [0.3413] & {$[0.7853]$} \\
\hline \multirow[t]{2}{*}{ SQM_RET } & 0.0034 & 0.004 & 0.0052 & 0.0053 \\
\hline & [0.7062] & [0.6485] & [0.5818] & {$[0.5671]$} \\
\hline \multirow[t]{2}{*}{ Cash flow rights } & $-1.7386 * * *$ & & & \\
\hline & [0.0000] & & & \\
\hline \multirow[t]{2}{*}{ Voting Rights } & & $-2.1613 * * *$ & & \\
\hline & & [0.0000] & & \\
\hline \multirow[t]{2}{*}{ Wedge } & & & -0.0484 & \\
\hline & & & [0.6269] & \\
\hline \multirow[t]{2}{*}{ Family } & & & & $-0.1209 * * *$ \\
\hline & & & & {$[0.0001]$} \\
\hline \multirow[t]{2}{*}{ State } & & & & $-0.0821 * *$ \\
\hline & & & & [0.0299] \\
\hline \multirow[t]{2}{*}{ Coalitions } & & & & $-0.0766^{* *}$ \\
\hline & & & & [0.0266] \\
\hline \multirow[t]{2}{*}{ Controlled_WH } & & & & $-0.1193 * * *$ \\
\hline & & & & {$[0.0078]$} \\
\hline \multirow[t]{2}{*}{ PrivateEquity } & & & & -0.0062 \\
\hline & & & & [0.8932] \\
\hline \multirow[t]{2}{*}{ Constant } & 0.0229 & 0.037 & $-0.1073 *$ & 0.0233 \\
\hline & [0.6979] & [0.5226] & {$[0.0586]$} & [0.7117] \\
\hline R-squared & 0.1369 & 0.1648 & 0.0423 & 0.1472 \\
\hline Observations & 223 & 223 & 223 & 223 \\
\hline
\end{tabular}


TABLE 7

Shareholder dissent on SOP, Board characteristics and investor activism

\begin{tabular}{|c|c|c|c|c|}
\hline \multirow[t]{2}{*}{ LNTotAssets } & \multirow{2}{*}{$\begin{array}{l}0.0186^{*} \\
{[0.0935]}\end{array}$} & \multirow{2}{*}{$\begin{array}{l}0.0193^{*} \\
{[0.0748]}\end{array}$} & 0.0075 & -0.0006 \\
\hline & & & [0.5242] & [0.9627] \\
\hline \multirow[t]{2}{*}{$M / B$} & 0.0017 & 0.0008 & 0.0018 & 0.0012 \\
\hline & [0.5118] & [0.7531] & [0.4776] & [0.6319] \\
\hline \multirow[t]{2}{*}{ ROA } & -0.046 & -0.0402 & -0.0669 & -0.1014 \\
\hline & [0.4380] & [0.5109] & {$[0.2600]$} & [0.1015] \\
\hline \multirow[t]{2}{*}{ SQM_RET } & 0.0072 & 0.0071 & 0.0029 & 0.0062 \\
\hline & [0.4470] & [0.4677] & [0.7547] & [0.5005] \\
\hline \multirow[t]{2}{*}{ Fin/Nonfin } & $-0.0616^{* *}$ & $-0.0520^{*}$ & $-0.0549 *$ & -0.0328 \\
\hline & [0.0465] & [0.0980] & [0.0778] & [0.2952] \\
\hline \multirow[t]{2}{*}{ Chairman-CEO } & 0.0087 & -0.0047 & & \\
\hline & [0.6072] & [0.7940] & & \\
\hline \multirow[t]{2}{*}{ CEO_Age } & -0.001 & -0.0009 & & \\
\hline & [0.1954] & [0.3088] & & \\
\hline \multirow[t]{2}{*}{ Min. Directors in Board } & $0.0495^{* * *}$ & & & \\
\hline & [0.0022] & & & \\
\hline \multirow[t]{2}{*}{ Assogestioni directors in Board } & 0.0243 & & & \\
\hline & [0.5312] & & & \\
\hline \multirow[t]{2}{*}{ Min. Directors in Rem. Com. } & & $0.0826^{* * *}$ & & \\
\hline & & [0.0001] & & \\
\hline \multirow[t]{2}{*}{ Assogestioni directors in Rem. Com. } & & -0.0122 & & \\
\hline & & {$[0.7740]$} & & \\
\hline \multirow[t]{2}{*}{ Presence of Foreign Funds (\%) } & & & $0.2046^{*}$ & \\
\hline & & & [0.0962] & \\
\hline \multirow[t]{2}{*}{ Presence of Italian Insurance and Banks (\%) } & & & 0.4246 & \\
\hline & & & [0.1926] & \\
\hline \multirow[t]{2}{*}{ Presence of Italian Funds (\%) } & & & 4.5643 & \\
\hline & & & [0.1734] & \\
\hline \multirow[t]{2}{*}{ Dummy Foreign Funds } & & & & 0.0223 \\
\hline & & & & [0.2653] \\
\hline \multirow[t]{2}{*}{ Dummy Italian Insurance and Banks } & & & & 0.0127 \\
\hline & & & & [0.5279] \\
\hline \multirow[t]{2}{*}{ Dummy Italian Funds } & & & & $0.1008^{* * *}$ \\
\hline & & & & {$[0.0001]$} \\
\hline \multirow[t]{2}{*}{ Constant } & -0.0266 & -0.031 & -0.0067 & 0.0218 \\
\hline & [0.7181] & {$[0.6780]$} & [0.9196] & [0.7413] \\
\hline R-squared & 0.0958 & 0.1316 & 0.076 & 0.1148 \\
\hline Observations & 219 & 191 & 223 & 223 \\
\hline
\end{tabular}

$*, * *, * * *$ indicate a $\mathrm{p}$-value of coefficients $<10 \%, 5 \%, 1 \%$, respectively 
TABLE 8

Shareholder dissent on SOP: Complete model

\begin{tabular}{|c|c|c|c|c|c|c|}
\hline \multirow[t]{2}{*}{ LNTotAssets } & 0.0113 & 0.0167 & 0.0018 & & & \\
\hline & [0.3651] & [0.1524] & [0.8836] & & & \\
\hline \multirow[t]{2}{*}{$M / B$} & 0.0019 & 0.0019 & 0.001 & 0.0016 & 0.0016 & 0.0009 \\
\hline & [0.4303] & [0.4110] & [0.6893] & [0.4818] & [0.5005] & [0.6988] \\
\hline \multirow[t]{2}{*}{ Fin/Nonfin } & -0.0189 & -0.0264 & -0.0189 & -0.0049 & -0.0059 & -0.0165 \\
\hline & [0.5475] & [0.3927] & [0.5335] & [0.8587] & [0.8294] & [0.5141] \\
\hline \multirow[t]{2}{*}{ ROA } & 0.0105 & 0.0117 & -0.0544 & 0.0137 & 0.0177 & -0.0531 \\
\hline & {$[0.8565]$} & [0.8409] & [0.3494] & [0.8128] & [0.7604] & [0.3540] \\
\hline \multirow[t]{2}{*}{ SQM_RET } & 0.0036 & 0.0037 & 0.0056 & 0.0028 & 0.0026 & 0.0055 \\
\hline & [0.6938] & [0.6788] & [0.5484] & {$[0.7596]$} & {$[0.7700]$} & [0.5537] \\
\hline \multirow[t]{2}{*}{ Dummy Low Disclosure } & $0.0887 * * *$ & $0.0856 * * *$ & & $0.0856 * * *$ & $0.0800 * * *$ & \\
\hline & [0.0009] & [0.0011] & & [0.0013] & [0.0020] & \\
\hline \multirow[t]{2}{*}{ Cash flow rights } & $-0.1173 * * *$ & $-0.1207 * * *$ & $-0.1288 * * *$ & $-0.1147 * * *$ & $-0.1166 * * *$ & $-0.1281 * * *$ \\
\hline & {$[0.0046]$} & [0.0033] & [0.0014] & {$[0.0054]$} & [0.0045] & [0.0013] \\
\hline \multirow[t]{2}{*}{ CEOTotComp } & 0.0000 & & 0.0000 & 0.0000 & & 0.0000 \\
\hline & [0.2469] & & [0.4124] & [0.1134] & & {$[0.3625]$} \\
\hline \multirow[t]{2}{*}{ Min. Directors in Rem. Com. } & $0.0718^{* * *}$ & $0.0671^{* * *}$ & $0.0668 * * *$ & $0.0758 * * *$ & $0.0716^{* * *}$ & $0.0673^{* * *}$ \\
\hline & [0.0015] & [0.0024] & [0.0010] & [0.0006] & {$[0.0012]$} & {$[0.0008]$} \\
\hline \multirow[t]{2}{*}{ Assogestioni directors in Rem. Com. } & $-0.0668 *$ & -0.0603 & -0.0602 & $-0.0662 *$ & -0.0557 & -0.0597 \\
\hline & [0.0948] & [0.1259] & [0.1443] & [0.0979] & [0.1573] & [0.1451] \\
\hline \multirow[t]{2}{*}{ Presence of Foreign Inst. Funds (\%) } & -0.0044 & -0.0094 & -0.0176 & 0.0396 & 0.0632 & -0.0099 \\
\hline & [0.9721] & [0.9410] & [0.8934] & [0.7358] & [0.5882] & [0.9339] \\
\hline \multirow[t]{2}{*}{ Dummy Italian Institutional Funds } & $0.0634 * *$ & $0.0691 * *$ & $0.0772 * * *$ & $0.0654 * *$ & $0.0752 * * *$ & $0.0776 * * *$ \\
\hline & {$[0.0237]$} & [0.0122] & [0.0084] & [0.0193] & {$[0.0060]$} & [0.0077] \\
\hline \multirow[t]{2}{*}{ Constant } & 0.0005 & -0.023 & 0.0746 & $0.0613^{* *}$ & $0.0687^{* *}$ & $0.0839 * * *$ \\
\hline & [0.9947] & [0.7388] & {$[0.2765]$} & {$[0.0228]$} & [0.0101] & [0.0012] \\
\hline R-squared & 0.305 & 0.2978 & 0.2315 & 0.301 & 0.288 & 0.2314 \\
\hline Observations & 158 & 159 & 194 & 158 & 159 & 194 \\
\hline
\end{tabular}

\footnotetext{
$*, * *, * * *$ indicate a $\mathrm{p}$-value of coefficients $<10 \%, 5 \%, 1 \%$, respectively
} 
TABLE 9

"High" shareholder dissent on SOP, CEO compensation and disclosure (Logit model)

\begin{tabular}{|c|c|c|c|c|c|c|c|c|}
\hline \multirow[t]{2}{*}{ LNTotAssets } & $1.2679 * * *$ & & & & & & & \\
\hline & {$[0.0000]$} & & & & & & & \\
\hline \multirow[t]{2}{*}{$M / B$} & 0.0805 & 0.0485 & 0.0565 & 0.0407 & 0.0403 & 0.0427 & 0.0391 & 0.064 \\
\hline & {$[0.4200]$} & {$[0.5063]$} & [0.4322] & [0.5664] & {$[0.5753]$} & [0.5231] & [0.5805] & [0.3789] \\
\hline \multirow[t]{2}{*}{ Fin/Nonfin } & $-3.0872 * * *$ & -1.2246 & $-1.5869 *$ & -1.0612 & -1.1422 & -0.8681 & -1.0939 & $-1.3614^{*}$ \\
\hline & {$[0.0019]$} & [0.1151] & {$[0.0524]$} & [0.1656] & {$[0.1462]$} & [0.2622] & [0.1533] & {$[0.0821]$} \\
\hline \multirow[t]{2}{*}{ ROA } & 0.7192 & 0.3008 & 0.5423 & 0.8697 & 0.6968 & 0.687 & 1.2205 & 0.4196 \\
\hline & {$[0.7115]$} & {$[0.8210]$} & [0.6881] & [0.5139] & [0.5995] & [0.5961] & [0.3679] & [0.7579] \\
\hline \multirow{2}{*}{ Dummy Low Disclosur } & $\quad 0.6231$ & & & & & & & \\
\hline & [0.2813] & & & & & & & \\
\hline \multirow[t]{2}{*}{ CEOTotComp } & & $0.0003^{* * *}$ & & & & & & \\
\hline & & {$[0.0073]$} & & & & & & \\
\hline \multirow[t]{2}{*}{ CEOFixedPay } & & & $0.0007^{* * *}$ & & & & & \\
\hline & & & {$[0.0011]$} & & & & & \\
\hline \multirow[t]{2}{*}{ CEOVarCash } & & & & 0.0002 & & & & \\
\hline & & & & {$[0.1360]$} & & & & \\
\hline \multirow[t]{2}{*}{ CEOEquity } & & & & & $0.0010^{* *}$ & & & \\
\hline & & & & & {$[0.0323]$} & & & \\
\hline \multirow[t]{2}{*}{ CEOExcessComp } & & & & & & $0.3504^{*}$ & & \\
\hline & & & & & & [0.0622] & & \\
\hline \multirow[t]{2}{*}{ Dummy Ceo turnover } & & & & & & & 0.448 & \\
\hline & & & & & & & {$[0.3954]$} & \\
\hline \multirow[t]{2}{*}{ DumQuartTotComp3 } & & & & & & & & $-0.9234 * *$ \\
\hline & & & & & & & & [0.0283] \\
\hline \multirow[t]{2}{*}{ DumQuartTotComp2 } & & & & & & & & $-1.1245^{* *}$ \\
\hline & & & & & & & & [0.0105] \\
\hline \multirow[t]{2}{*}{ DumQuartTotComp1 } & & & & & & & & $-1.5944 * * *$ \\
\hline & & & & & & & & [0.0014] \\
\hline \multirow[t]{2}{*}{ Constant } & $-8.6775 * * *$ & $-1.5126 * * *$ & $-1.6956 * * *$ & $-1.2168 * * *$ & $-1.2670 * * *$ & $-1.1932 * * *$ & $-1.1984 * * *$ & -0.3172 \\
\hline & {$[0.0000]$} & {$[0.0000]$} & {$[0.0000]$} & {$[0.0000]$} & {$[0.0000]$} & {$[0.0000]$} & {$[0.0000]$} & [0.2862] \\
\hline Pseudo R-squared & 0.1705 & 0.0715 & 0.0638 & 0.032 & 0.0629 & 0.0311 & 0.0202 & 0.0709 \\
\hline Observations & 172 & 225 & 225 & 225 & 225 & 218 & 225 & 225 \\
\hline
\end{tabular}

$*, * *, * * *$ indicate a $\mathrm{p}$-value of coefficients $<10 \%, 5 \%, 1 \%$, respectively 
TABLE 10

"High" shareholder dissent on SOP and investor activism (Logit model)

\begin{tabular}{|c|c|c|c|c|}
\hline \multirow[t]{2}{*}{ LNTotAssets } & $1.0799 * * *$ & $1.1108^{* * *}$ & $0.6953^{* *}$ & $0.7206 * *$ \\
\hline & [0.0001] & {$[0.0000]$} & [0.0151] & [0.0174] \\
\hline \multirow[t]{2}{*}{$M / B$} & 0.1059 & 0.1156 & 0.0999 & 0.1192 \\
\hline & [0.2732] & [0.2400] & [0.2936] & [0.2699] \\
\hline \multirow[t]{2}{*}{ ROA } & -0.7959 & -0.9255 & $5 \quad-1.5562$ & -2.4358 \\
\hline & [0.6097] & [0.5554] & [0.2707] & [0.1004] \\
\hline \multirow[t]{2}{*}{ SQM_RET } & -0.0676 & -0.0937 & $7 \quad-0.1941$ & -0.0991 \\
\hline & [0.7825] & [0.7107] & [0.4468] & [0.6844] \\
\hline \multirow[t]{2}{*}{ Fin/Nonfin } & $-3.2920 * * *$ & $-3.1688 * * *$ & $-3.4381 * * *$ & $-2.7905 * * *$ \\
\hline & [0.0010] & [0.0011] & [0.0044] & [0.0054] \\
\hline \multirow[t]{2}{*}{ Chairman-CEO } & 0.2575 & 0.083 & & \\
\hline & [0.5214] & [0.8443] & & \\
\hline \multirow[t]{2}{*}{ CEO_Age } & -0.0148 & -0.0019 & & \\
\hline & [0.4562] & [0.9266] & & \\
\hline \multirow[t]{2}{*}{ Min. Directors in Bo } & $\quad 0.353$ & & & \\
\hline & [0.3438] & & & \\
\hline \multirow[t]{2}{*}{ Assogestioni directo } & $\quad 0.6053$ & & & \\
\hline & [0.4741] & & & \\
\hline \multicolumn{2}{|c|}{ Min. Directors in Rem. Com. } & $0.7422 *$ & & \\
\hline & & [0.0944] & & \\
\hline \multicolumn{2}{|c|}{ Assogestioni directors in Rem. Cor } & -0.4755 & & \\
\hline & & [0.6001] & & \\
\hline \multirow{2}{*}{\multicolumn{2}{|c|}{ Presence of Foreign Inst. Funds (\% }} & & $7.3034^{* *}$ & \\
\hline & & & [0.0180] & \\
\hline \multicolumn{3}{|c|}{ Presence of Italian Insurance and Banks (\%) } & 6.9701 & \\
\hline & & & [0.3429] & \\
\hline \multicolumn{3}{|c|}{ Presence of Italian Institutional Funds (\%) } & 86.1223 & \\
\hline & & & [0.2423] & \\
\hline \multirow[t]{2}{*}{ Dummy Foreign Inst. } & Funds & & & 0.8777 \\
\hline & & & & [0.1289] \\
\hline \multicolumn{3}{|c|}{ Dummy Italian Insurance and Banks } & & -0.0455 \\
\hline & & & & [0.9215] \\
\hline \multicolumn{2}{|c|}{ Dummy Italian Institutional Funds } & & & $1.6797^{* * *}$ \\
\hline & & & & [0.0022] \\
\hline \multirow[t]{2}{*}{ Constant } & $-6.8362^{* * *}$ & $-7.5829 * * *$ & $-5.4341 * * *$ & $-6.1084 * * *$ \\
\hline & {$[0.0002]$} & {$[0.0001]$} & {$[0.0010]$} & [0.0002] \\
\hline Pseudo R-squared & 0.1505 & 0.1529 & 0.1892 & $\quad 0.1957$ \\
\hline Observations & 219 & 191 & 223 & 223 \\
\hline
\end{tabular}

$*, * *, * * *$ indicate a $\mathrm{p}$-value of coefficients $<10 \%, 5 \%, 1 \%$, respectively 
TABLE 11

"High" shareholder dissent: Complete Logit model

\begin{tabular}{|c|c|c|c|c|c|c|}
\hline \multirow[t]{2}{*}{ LNTotAssets } & 0.6315 & $1.0241^{* * *}$ & $0.6994 * *$ & & & \\
\hline & {$[0.1096]$} & [0.0019] & {$[0.0271]$} & & & \\
\hline \multirow[t]{2}{*}{$\mathrm{M} / \mathrm{B}$} & 0.0627 & 0.0734 & 0.0874 & 0.0453 & 0.0387 & 0.0521 \\
\hline & {$[0.4158]$} & {$[0.4026]$} & {$[0.3346]$} & {$[0.4781]$} & {$[0.5221]$} & {$[0.4166]$} \\
\hline \multirow[t]{2}{*}{ Fin/Nonfin } & $-3.2393 * *$ & $-3.7139 * * *$ & $-3.3862 * * *$ & $-2.2656^{*}$ & $-1.9773 *$ & $-2.1514^{*}$ \\
\hline & {$[0.0179]$} & {$[0.0045]$} & {$[0.0076]$} & {$[0.0600]$} & [0.0795] & {$[0.0516]$} \\
\hline \multirow[t]{2}{*}{ ROA } & -0.9399 & -0.5654 & -1.4733 & -0.9021 & -0.4239 & -0.9282 \\
\hline & {$[0.6326]$} & {$[0.7831]$} & {$[0.3697]$} & {$[0.6079]$} & {$[0.8006]$} & {$[0.5400]$} \\
\hline \multirow[t]{2}{*}{ SQM_RET } & -0.2859 & -0.2903 & -0.2253 & -0.2856 & -0.31 & -0.25 \\
\hline & {$[0.3672]$} & {$[0.3495]$} & {$[0.4247]$} & {$[0.3498]$} & {$[0.2955]$} & {$[0.3701]$} \\
\hline \multirow[t]{2}{*}{ Dummy Low Disclosure } & 0.3477 & 0.3523 & & 0.1857 & -0.0094 & \\
\hline & {$[0.6384]$} & {$[0.6310]$} & & {$[0.7971]$} & {$[0.9891]$} & \\
\hline \multirow[t]{2}{*}{ Cash flow rights } & $-2.3085^{*}$ & $-2.2421^{*}$ & $-2.6789 * *$ & $-1.9902 *$ & -1.7774 & $-2.2085^{* *}$ \\
\hline & [0.0543] & [0.0543] & {$[0.0130]$} & [0.0847] & {$[0.1008]$} & [0.0317] \\
\hline \multirow[t]{2}{*}{ CEOTotComp } & $0.0003^{*}$ & & 0.0001 & $0.0005 * * *$ & & $0.0002^{*}$ \\
\hline & [0.0823] & & {$[0.1290]$} & [0.0029] & & {$[0.0542]$} \\
\hline \multirow[t]{2}{*}{ Min. Directors in Rem. Com. } & $1.2485^{* *}$ & 0.8883 & $0.8332^{*}$ & $1.4636 * * *$ & $1.0193 * *$ & $0.9417^{* *}$ \\
\hline & [0.0303] & [0.1063] & {$[0.0762]$} & {$[0.0079]$} & {$[0.0482]$} & [0.0395] \\
\hline \multirow[t]{2}{*}{ Assogestioni directors in Rem. Com. } & $-2.2654 *$ & $-1.9789 *$ & $-2.0685^{*}$ & $-1.8773^{*}$ & -1.4197 & -1.6237 \\
\hline & [0.0539] & [0.0732] & {$[0.0554]$} & {$[0.0930]$} & {$[0.1680]$} & [0.1205] \\
\hline \multirow[t]{2}{*}{ Presence of Foreign Inst. Funds (\%) } & 4.6172 & 4.7397 & 4.9832 & 5.8013 & $8.8914^{* *}$ & $7.8661 * *$ \\
\hline & [0.2249] & {$[0.2113]$} & {$[0.1726]$} & {$[0.1194]$} & {$[0.0160]$} & {$[0.0264]$} \\
\hline \multirow[t]{2}{*}{ Dummy Italian Institutional Funds } & 0.5168 & 0.6561 & 0.8354 & 0.6434 & 0.9433 & 0.95 \\
\hline & {$[0.4540]$} & {$[0.3200]$} & [0.1988] & {$[0.3453]$} & {$[0.1310]$} & [0.1332] \\
\hline \multirow[t]{2}{*}{ Constant } & $-4.3823 * *$ & $-6.2105^{* * *}$ & $-4.3517 * *$ & -1.1651 & -0.5652 & -0.7023 \\
\hline & [0.0442] & [0.0017] & [0.0146] & {$[0.1214]$} & [0.4138] & [0.2639] \\
\hline R-squared & 0.2851 & 0.2572 & 0.2514 & 0.2712 & 0.2014 & 0.2288 \\
\hline Observations & 158 & 159 & 194 & 158 & 159 & 194 \\
\hline
\end{tabular}

\footnotetext{
$*, * *, * * *$ indicate a $\mathrm{p}$-value of coefficients $<10 \%, 5 \%, 1 \%$, respectively
} 